Article

\title{
The Value of Business-Government Ties for Manufacturing Firms' Product Innovation during Institutional Transition in China
}

\author{
Chun Yang ${ }^{1,2}$, Bart Bossink ${ }^{1, *}$ and Peter Peverelli ${ }^{3}$ [C \\ 1 Faculty of Sciences, Section of Science, Business \& Innovation, Vrije Universiteit Amsterdam, \\ 1081 HV Amsterdam, The Netherlands; yangchun09@gmail.com \\ 2 Department of Public Administration, Hunan University, No. 2 Lushan Rd., Changsha 410082, China \\ 3 Amsterdam Business Research Institute, Vrije Universiteit Amsterdam, 1081 HV Amsterdam, \\ The Netherlands; p.j.peverelli@vu.nl \\ * Correspondence: b.a.g.bossink@vu.nl
}

Received: 13 November 2018; Accepted: 18 December 2018; Published: 22 December 2018

check for updates

\begin{abstract}
This study investigates how firms invest in building and maintaining business-government (B-G) ties when they aim to innovate in regions where, due to institutional transitions, institutional contexts differ remarkably. Using data from the China Enterprise Survey of the World Bank, empirical findings suggest that the influence of B-G ties on Chinese firms' product innovation is different in distinctive institutional contexts in China. More specifically, during institutional transition, B-G ties become less efficient for facilitating product innovation when regional legal institutions and infrastructural supporting systems in a region are more stable, fair, and efficient. By contrast, during institutional transition, a positive effect of $\mathrm{B}-\mathrm{G}$ ties on firm product innovation in a region becomes more significant when financial systems are relatively advanced. In addition to this, the value of $B-G$ ties for firm product innovation appears to be more stable when business regulation develops within subnational regions.
\end{abstract}

Keywords: business-government ties; institutional transition; institution-based view of business strategy; manufacturing firms' product innovation; China

\section{Introduction}

After more than 30 years of rapid development, Chinese manufacturing now gradually shifts its development model from low-tech and China-made to high-tech and China-innovated. To adapt to this trend, the Chinese government continuously contributes to institutional reforms, leading to institutional transitions which characterize China's transitional economy [1]. During this transition process, market forces gradually become more dominant and government controls become weaker $[1,2]$. To move towards a more market-driven system that develops itself through a continuous process of ongoing product innovation, China may issue new rules and abort obsolete regulations frequently, which can lead to rapid changes in social, economic, legal, and political institutions [3,4]. Such changes may challenge firms' operations with regard to innovation, since they often restructure the rules firms are used to. In such a situation, the way manufacturing firms in contemporary China achieve superior innovation performance has attracted an increasing attention in innovation management literature $[1,2,5,6]$. As a strategic response to such turbulence, business-government ties (hereafter B-G ties), that is, senior managers' links with public authorities, government officials, and agencies [2,7], are regularly witnessed in practice as an instrument to facilitate senior managers' companies' innovative activities [2,8-10]. As a substitute for missing formal institutions, B-G ties can help 
firms to gain access to external resources, technology, and information, and enable them to manage environmental uncertainties and constraints $[1,11]$. Existing literature has extensively confirmed the influence of B-G ties on firms' performance [2,12], on firms' strategy [11,13], and also on firms' product innovation $[14,15]$.

However, research on the influence of B-G ties on firms' product innovation may lead to ambiguous arguments or conclusions, especially in contexts that are in institutional transition. Some studies show positive effects; they, for example, present U-shaped or inverted U-shaped effects; and some studies show negative effects of B-G ties on firms' product innovation [14-17]. Such multifarious findings indicate that "B-G ties-firms' product innovation links" may depend on contingent factors, such as institutional settings. In emerging economies like China, B-G ties are embedded in usually diverse subnational regions $[18,19]$. For example, China's economic systems in coastal cities are reported to be more open and market-oriented than those in Central and Western Chinese cities [20]. Thus, more insight into the influence of institutional diversity can help to further clarify the ambiguous relationship between B-G ties and firms' product innovation.

Ambiguous conclusions can also arise from empirical research that is based on the institution-based view (IBV) of business strategy [1,21]. In IBV, the institutions, that is, 'the rules of the game' [22], are seen as key determinants of firms' strategic behaviors [1,6,23-25]. IBV postulates that institutions influence firms' operations through shaping the mechanisms or formal institutions firms have to deal with [22], such as managerial incentive schemes, transaction and agency cost structures, and resource allocation practices [26]. IBV proposes that B-G ties become less important as these mechanisms or formal institutions develop. Furthermore, B-G ties would play a more important role in securing business exchanges in regions where formal market-based institutions are lacking or relatively underdeveloped [1,21,23-25]. However, empirical research reports inconsistent findings. For example, Peng corroborates that the value of $B-G$ ties would decline as the institutions are more developed [1], but Michelson and Shi et al. argue that the value of $B-G$ ties remains intact as institutions become more developed $[27,28]$. A possible explanation for these incompatible results is that most given studies tend to treat institutions as a background, as a single entity, or as one dimension $[11,15]$. Therefore, a possible research response to these varying arguments is to examine the presence and specific effects of B-G ties on firms' product innovation in varying institutional contexts; institutional contexts that are complex and consist of several components [11,29]. Because multiple institutions instead of one single institution may influence the value of B-G ties for firms [11,21,29-31], a research focus on multiple institutional components could deepen our understanding of the role of B-G ties on firms' product innovation in transitional contexts [11,29,30]. Based on the above, this study focuses on the question: To what extent are B-G ties influencing Chinese manufacturing firms' product innovation in regions with varying institutional arrangements?

Building on IBV, this study aims to assess to what extent the role of B-G ties in firms' product innovation varies across subnational cities, with different institutional arrangements, in China. To this end, this study decomposes the institutions into basic components, that is, legal and economic institutions, which are further decomposed into subcomponents [32]. This multiple institutional component perspective is used to analyze the direct value of firm-level B-G ties on firms' product innovation, and to gain an insight into how Chinese city-level institutional components moderate this relationship.

Using multilevel models, the study unfolds an analysis by focusing on the Chinese context with World Bank survey data [33,34]. The empirical findings indicate that B-G ties are positively associated with firms' product innovation within subnational cities of China no matter to what extent the institutions are developed and further develop. It also finds that B-G ties are less positively associated with firms' product innovation in cities with a higher developmental level of legal institutions and infrastructural institutions and are more positively associated in cities with a higher development level of financial institutions. 
These findings contribute to extant literature in two ways. Firstly, they help to clarify to what extent B-G ties continue to influence firms' product innovation in emerging economies. Secondly, this study extends the analytic boundaries of IBV by validating the differentiated effects of multiple institutional components on "B-G ties-firms' product innovation links". In addition to this, practitioners can benefit from these insights by means of investing time and energy into developing B-G ties that support their business and tailor their activities to the specific institutional context they are in.

The remainder of this paper is arranged as follows. Section 2 reviews the literature and develops hypotheses concerning the direct effect of B-G ties on firms' product innovation and concerning how institutional components may shape this relationship. Section 3 describes the Chinese Enterprise Survey of the World Bank and the multilevel regression model, which are used to test the hypotheses. Section 4 presents the research results, which finally, in Section 5, are discussed.

\section{Theory and Hypotheses Development}

\subsection{The Value of B-G Ties for Firms' Product Innovation}

Social capital embedded in $B-G$ ties is a unique asset for firm performance $[2,9,35]$. In other words, B-G ties can better leverage government-dominated information and resources for firms' operations, such as competitive advantage building [2], survival [12], market entry [13], sell-off [11], and particularly, innovation activities $[8,14,15]$. Transitional economies like China are usually dominated by a lack of formal institutions, whereas the Chinese government's considerable control on strategic resources remains intact. Social capital from B-G ties can help firms to deal with such insufficient formal institutions and acquire needed resources [35]. Therefore, B-G ties can have a positive influence on firms' product innovation by means of mitigating environmental risks, obtaining regulatory favors, and leveraging strategic resources that cannot be easily acquired by non-B-G-ties-connected rivals $[2,8,11,14]$.

Firstly, B-G ties enable firms to mitigate environmental uncertainties and buffer innovation risks that arise from lack of institution development [12]. In an emerging economy, "institutional voids" usually dominate and can lead to costly and inefficient market transactions [36,37], which would significantly curb firms' investments in product innovation. An emerging economy often has relatively underdeveloped and limited institutional support for firms' innovation activity [38]. Under such conditions, as a substitute for the "institutional voids", B-G ties can help firms to overcome the (un)expected risks and uncertainties related to this institutional setting. Intensive B-G ties can lead to higher political legitimacy $[5,11]$. Political legitimacy may not only shape firms' activities to align their business with the government's interests and, through this, to obtain more government favors but may also make their innovative products more consumer-acceptable [39]. B-G ties can also enable firms to generate mechanisms that enforce the protection of their intellectual property rights (IPR) $[11,40]$. The legal systems, particularly IPR protection is often weak, inefficient, and incomplete in transitional China [1]. Such inadequate IPR protection environments may discourage firms' investment in innovation due to the high transaction costs associated with protecting their innovative products [22]. B-G ties can provide shortcuts for firms to get institutional support and protection and help them to reap the benefits of innovation $[2,41]$.

Secondly, B-G ties may form social capital, which can help firms to acquire regulatory resources. During institutional transitions, changing business regulations often make markets more unpredictable, whereas good connections with governments can enable firms to deal with such constraints more effectively. For example, Chinese local governments usually regulate the allocation of business and economic resources through implementing regional "Five-Year Plans", high-tech industry development plans, and localized policies and regulations. By intensive (in)formal interactions with government officials, a firm may be better informed about upcoming new policies and emerging regulations. This first-hand regulation information helps firms to decrease the negative effects arising from policy 
uncertainties, and to identify the technological opportunities that governments intend to create. In addition, through regular interactions with the government, firms may lobby officials and bureaus to devise or revise regulations in line with their wishes and enable them to obtain policy favors [5,22], such as the government procurement of new and innovative products [42]. It can be argued that firms which maintain good interactions with governmental officials usually benefit from regulatory resource allocation [43]. The Chinese government, at all levels, still controls, regulates, and allocates a large volume of regulatory resources, such as trade permits, tax deduction, and R\&D support and subsidies [44,45]. Obtaining these resources makes firms more confident in investing in new technology. The reform goal of the current Chinese government is to build an innovation-oriented economy. Under such conditions, firms with intensive connections with government officials may be offered priority to allocate regulatory resources for innovation purposes [9].

Thirdly, social capital embedded in B-G ties can enable firms to leverage strategic business resources and secure government services. The Chinese government still plays a dominant role in strategic resource allocation, such as finance for innovation (e.g., state-controlled venture capital, government dominated high-tech start-ups seed, governmental research funding) [46]. To obtain these financial resources in a more efficient way, firms often resort to B-G ties, which shelters them from information asymmetry. In addition, B-G ties can also strengthen organizational relationships. Official positions in China are often changing and rotating. They usually urge managers to restructure $B-G$ ties when a new appointment is approved [38], since connections with new officials are helpful for firms to maintain institutional support, such as securing government favors and services. In contemporary China, the primary interest of officials is to increase the gross domestic product (GDP) in a sustainable and innovative way, which in turn promotes their political positions. Firms' purpose is to get an economic return from the Chinese government's innovation and sustainability investments [20]. Apparently, business goals and government interests converge when they can 'help' each other. Therefore, officials would prioritize government service providing, such as land and infrastructure provisions, business permissions, and regulatory approvals, to prospective innovative business projects that contribute to the achievement of governmental ends [15,47]. This leads to the first hypothesis:

Hypothesis 1 (H1). In transitional China, B-G ties have positive effects on manufacturing firms' product innovation.

\subsection{Contingent Effects of Specific Institutional Contexts}

\subsubsection{The Institutions and Institutional Transitions in China}

As 'the rules of the game' [22], institutions can regulate, motivate, and constrain firms to behave, produce, innovate, and invest [6]. B-G ties are embedded in specific institutional contexts [2,48-50] and institutional changes can shape the value of B-G ties $[18,36,51,52]$. Generally, the institutional environment can contribute to the value of $B-G$ ties for firms' innovation performance through shaping the contextual conditions wherein $B-G$ ties are situated. Such contextual conditions are, for example, the issuing of business certificates (e.g., trade permits, licenses), innovation-related resource allocation (e.g., R\&D subsidies), bureaucratic procedure simplification (e.g., startup registration, tax administration), legitimacy provision, and regulatory policy implementation [53-55]. Imperfect institutions often distort resource allocation and can discourage firms' investment in product innovation; by contrast, an adequate institutional system generally may cultivate firms' allocation of innovation-related resources and motivate firms' new technology development. Based on IBV logic, it can be argued that firms in underdeveloped institutional systems are likely to depend more on relational governance (e.g., B-G ties) to obtain necessary resources and overcome constraints, while firms rely less on relational strategies (e.g., B-G ties) in institutional systems that are more developed $[1,2,5,9,23,38,56]$.

Institutions are multidimensional [57], and different components develop in different ways [11,58]. To be specific, certain institutional components may develop towards a high and advanced level, 
while others may stagnate or even regress [11,59]. For example, business regulations in Eastern China are becoming more efficient and market-based, while they significantly lag behind in the cities of Western China [20]. Moreover, institutional components provide differentiated support for firms' product innovation, which may make the value of $\mathrm{B}-\mathrm{G}$ ties more complicated in transitional China. For example, legal systems lend more support for IPR protection and can create conducive and fair environments for motivating product innovation. Business regulation regulates resource allocation and distribution, such as approval provisions, and tax reductions for research and development. Financial systems create financial intermediaries for firms to access capital markets. These examples indicate that specific institutional components provide unique support, motivation, and constraints for firms' product innovation [11,14].

Currently, China experiences institutional transitions. First, it is frequently argued that market institutions that support firms' resource allocation and business exchanges remain weak and need to be more efficient $[2,60]$, although China's central government has already devoted nearly 40 years to economic reform. For example, various levels of the Chinese government still control a large proportion of the country's economic resources [21]. As a consequence, the government still has an important influence on firms' innovation and market activities. Second, the unbalanced development of subnational regions dominates the country. Since initiating reform in 1978, China has gradually moved to economic decentralization [3]. This decentralization usually invoked inter-regional competition, market fragmentation, and accordingly, an uneven development of subnational regions [20,61]. As a consequence, China now comprises three distinguished parts according to their statuses of economic developments, i.e., the wealthy eastern region, the booming central region, and the developing western region. Accompanying this unbalanced intracountry development, subnational regions gradually differ in the development and maturity levels of their institutions [51,61,62]. In other words, the unbalanced development leads to varying institutional situations and changes within subnational regions [61,63]. The inter- and intraregional developmental differences dominate the development of the institutional systems [20,27]. Third, subnational regions gradually formed localized institutional systems during reforms. Accompanying the Chinese reform since 1978, the central government gradually delegated power to the lower-level government. As a result, local governments are authorized to devise their own economic and technological policies [26], such as implementing tax regulations, setting up science parks and industrial development zones, and making preferential procurements. As a consequence of these local reforms, a modern China is envisioned and realized with subnational areas where institutional settings differ. The unbalanced institutional developments suggest that not all firms benefit equally from B-G ties in transitional China $[4,43,51,62,64]$. It is expected that the value of B-G ties for firms' product innovation depends on the specific institutional contexts where firms operate $[11,29,65]$.

To enrich the understanding of this, the effects of specific institutional components on B-G ties' influence on firms' product innovation can be further explored, and basic concepts that are used can be defined. This study first defines institutional development as the process by which institutions move to be more efficient and market-driven within subnational regions of China [1,3]; a higher level of institutional development is defined as a situation in which institutions are more stable, fair, and efficient [32]. North distinguishes two dimensions of institutions, i.e., formal institutions and informal institutions [22]. Following this distinction, this study concentrates explicitly on formal institutions. It further decomposes formal institutions into legal institutions and economic institutions, due to their determinant role in China $[18,32,36,52,66]$. For example, Zhu et al. identified several major institutional barriers to Chinese firms' innovation, such as unfair competition, limited access to finance, lack of regulations, excessive taxation, and insufficient support systems [32]. Building on Zhu et al.'s findings, this study further decomposes the economic institutions into three subcomponents: Business regulations, financial systems, and infrastructural supporting systems. 


\subsubsection{Legal Institutions}

Legal institutions can influence the "B-G ties-firms' product innovation links" in several ways. First, legal institutions may motivate and constrain firms' investment in product innovation. Generally, stable, fair, transparent, and efficient legal institutions can provide adequate legal protection for organization operations, and can cultivate fair exchange environments for market activities, which can help to mitigate the risks and uncertainties arising from inadequate legal institutions, and by this lead, decrease transaction costs [67]. Particularly, an adequate legal IPR system can create substantial protection for firms' technological inventions, new products, and new brands, which may largely motivate firms' investment in innovation. As reported in the literature, IPR protection can substantially support firms' investments in research and development [68,69]. In addition to securing market environments, legal institutions can also enhance the enactment and enforcement of other formal institutions that can encourage innovation, such as technology trading rules, IPR regulations, and R\&D contracts. Due to a lack of legal protection, in regions with inadequate legal institutions, innovative firms usually suffer from rivals' imitations. Once firms get involved in IPR conflicts, they can also consider the opportunity to employ alternative channels to secure their innovative business, such as B-G ties to secure their business interests. Therefore, in transitional economies like China, government officials usually intervened in the operation of the judicial systems, and thus, institutional protection often flowed to firms with stronger B-G ties. As the country develops, generally, legal institutions are getting more independent and play an increasing role in supporting a market economy. Particularly, new specific laws are gradually issued and implemented. At the same time, more market-based channels for business exchanges emerge. The new laws can substantially secure such market-driven transactions. Therefore, in regions with more efficient legal institutions, firms may be more confident in acquiring the needed resources from the market through a bundle of legalized procedures and systems, rather than heavily relying on B-G ties $[2,16,22]$. Thus, governmental interventions may gradually decrease in these areas and the value of $B-G$ ties then may decrease [1]. By contrast, the importance of $B-G$ ties may remain relatively important in regions with less developed legal institutions. Lastly, legal institutions can influence the "B-G ties-product innovation links" via cultivating an institutional environment that is based on trust. Uncorrupted legal institutions can clearly define, structure, and secure the boundaries of market exchange, and can cultivate an atmosphere of trust between market and nonmarket agents, firms, and governmental officials $[15,47,55]$. In regions with more developed legal institutions, for example, firms may trust and rely more on legal procedures rather than on informal social ties to obtain government innovation funds and secure their investment in technological development. On the other hand, in an environment with relatively corrupted or incomplete legal institutions, managers may have to develop social ties with governmental officials to cultivate bilateral personal or organizational trust, and through this, gain access to support, protection, and legitimacy $[15,55]$. Empirically, Perks et al. found that managers tend to rely more on social ties when the support of the regulatory and legal institutions is lacking [70]. Overall, it can be argued that $\mathrm{B}-\mathrm{G}$ ties are more valuable for firms' product innovation in regions with less developed legal institutions $[56,71,72]$. This leads to the second hypothesis.

Hypothesis 2 (H2). The effect of B-G ties on Chinese manufacturing firms' product innovation is less positive when legal institutions are more developed.

\subsubsection{Economic Institutions}

Business regulations, such as tax or subsidy rules, can directly influence, shape, and determine firms' market activities and business transactions. For example, higher governmental R\&D subsidies or lower tax rates for new product sales could motivate firms' investment in new technology and in new product development. In a transitional economy like China, business regulations usually vary across cities $[11,27,58]$. Since 1978 , the central government had gradually authorized local governments to devise and implement their own business regulations, such as (R\&D-related) tax deduction or 
exemption, R\&D subsidies, and new product development support. Coming with this development, the content, quality, and efficiency of business regulations differ in subnational regions and these varying regulations accordingly determine firms' activities and performance differently [61]. Firms' responses, thus, will differ across subnational regions [1,56,61].

In regions with more developed business regulations (i.e., eastern and coastal cities in China), intermediaries for allocating business resources (e.g., human capital, employee training, technology transfer) are much more mature and efficient than in other parts of China. Regions that are lagging behind are usually dominated by a lack of such market intermediaries. Additionally, different agencies of local governments within such regions regularly issue specific rules to regulate firms' innovation and market activities. These rules are not always coordinated, which may confuse firms' prediction of the market [32]. Such conditions may lead firms to rely more on B-G ties. Moreover, business regulations also often determine the efficiency of regulatory resource allocation. Areas with developed business regulations have often fostered relatively transparent, complete, and robust systems and procedures for providing resources [2]. In these areas, trade permits, subsidies, and licenses are likely to be allocated to the most innovative and productive firms through well-known legal procedures [22]. Li et al. report that B-G ties play a less prominent role in facilitating firms' innovation in areas with stronger market institutions than in areas with weaker institutions [60]. By contrast, firms usually suffer more from lacking or inefficient business regulations in less institutionally developed regions (e.g., cities in Central and Western China). Thus, these innovative companies are inclined to integrate B-G ties with their strategies if they intend to invest there [1]. In other words, in cities with inefficient business regulations, managers more regularly build connections to government officials to deal with the potential uncertainties and risks that are arising from absent or conflicting business regulations $[37,56]$. Empirically, Zhang et al. validate that managers' time investment in B-G ties is positively associated with the performance of the firm that conducts exploratory innovation [72]. In addition, relatively developed business systems exert constraints on the deployment of individual power of government officials $[7,14,28]$. Therefore, officials in regions with a higher institutional development level are less willing to offer resources (e.g., government procurement of new products) via personal relations [7,14], which makes B-G ties less effective in areas with better developed business regulations. To conclude, in an environment with a set of transparent and coordinated business regulations, firms may rely less on B-G ties to deal with innovation constraints; in regions with less development of business regulations, innovative firms are likely to depend more on $B-G$ ties. This leads to the third hypothesis.

Hypothesis 3 (H3). The effect of B-G ties on Chinese manufacturing firms' product innovation is less positive when business regulations are more developed.

We define the financial systems as the rules that govern the financial operations and regulate the financial resource allocations. As widely reported, a lack of financial support can be a key barrier to firms' innovation in transitional China [32]. Although firms often prioritize internal finance for business activities [73], external finance is often attracted for long-term investments, such as technological innovation [32]. Regional financial systems determine how well these external financial resources flow to innovative firms [29,74]. Due to the unbalanced development of institutions within subnational regions, Chinese cities differ in the firms' opportunities to gain access to external financial capital (i.e., venture capital, bank loans, and government subsidies), the efficiency of the financing system, and the extent of governmental financial interventions [75]. In cities with limited and inefficient financial systems, government or state-owned organizations often dominate the financing channels, which make the capital limited and constrained to firms which know to find these organizations. Therefore, building or maintaining connections to government officials may be shortcuts to obtaining and securing such financial information and resources [1,45]. In these regions, government officials may have significant power in distributing bank loans, government-dominated seed funds, and R\&D support for firms' innovation projects. These resources may flow to firms that have strong B-G ties. 
As financial systems move to be more market-based in regions, various financing channels and options may emerge and new market-based financing rules are established [11,29]. Thus, firms in these regions can, for their innovation projects, resort to new market intermediaries, for example, the stock market, angel venture capital, personal capital, and corporate venture capital. Moreover, robust financial rules can secure firms' financing of, and investments in new technology. In addition, firms located in developed institutional areas may be relatively capable of developing financial reserves that would help these firms to develop buffer that protects them from innovation risks [76]. Increasing financing alternatives can decrease government interventions, and decline firms' dependence on government officials $[29,77]$. In other words, the market can provide more financing opportunities and efficient financing channels to facilitate firms' product innovation if the financial systems are more market-driven and higher developed. This leads to the fourth hypothesis.

Hypothesis 4 (H4). The effect of B-G ties on Chinese manufacturing firms' product innovation is less positive when financial systems are more developed.

An infrastructural supporting system here is defined as the set of rules that regulate, support, and constrain infrastructural services provision, such as electricity and telecommunication connections. Adequate infrastructural supporting services are another crucial factor to support firms' innovation and technology investment $[32,78]$. The infrastructural supporting systems regulate the provision of back-up resources or services, such as land provision, water, electricity, transportation, and telecommunication connections. Generally, deficiencies in such infrastructural services may result in system failures of business transactions and market distribution. To be more specific, substantial and efficient provision of infrastructural services is often seen as a precondition for firms to attract and recruit talent (e.g., engineers, researchers), develop new technologies, and market new products [32]. In transitional China, local governments are regularly responsible for investing in, and providing such infrastructural support. For example, the Chinese central government has gradually delegated local governments to sell and lease state-owned land resources for business purposes since 1978 . However, inter-regional differences dominate China's infrastructural service practices. In regions with an institutional development that lags behind, infrastructural service provision is far from institutionalized. Local governments there usually intervene in service processes (e.g., officials may change, abort, and approve the services), which makes service provision uncertain and full of risk. Therefore, senior managers are likely to invest time and energy in interacting with government officials to deal with the complicated and changing bureaucratic procedures $[1,71]$. Sometimes, firms even bribe officials to get things done [79]. In this manner, B-G ties are shortcuts for firms to get the expected governmental services and speed up the service process.

By contrast, in developed regions, new rules and regulations of infrastructural support gradually become institutionalized. First, more developed systems for providing infrastructural support services can motivate and secure more intermediaries for firms to get necessary services. Second, the systems increasingly support service provision through market or semimarket transactions. Third, the transparency of the infrastructural supporting system usually provides punishment mechanisms for the abuse of power of government officials, which curbs government interventions [14]. This means that the market offers firms more options to gain access to infrastructural support services, and the government provides infrastructural support services through market channels. Thus, the relatively developed infrastructural supporting systems may decrease firms' dependence on $B-G$ ties in obtaining infrastructural services [2,9], and limit the potential positive influence of B-G ties on product innovation. In China's eastern coastal cities, for example, firms can now usually obtain land through the auction market and acquire water and telecommunication connections from specialized enterprises in a more efficient way. This leads to the fifth hypothesis.

Hypothesis 5 (H5). The effect of B-G ties on Chinese manufacturing firms' product innovation is less positive when the infrastructural supporting systems are more developed. 
Overall, Figure 1 depicts the position of the hypothesized relationships in this study.

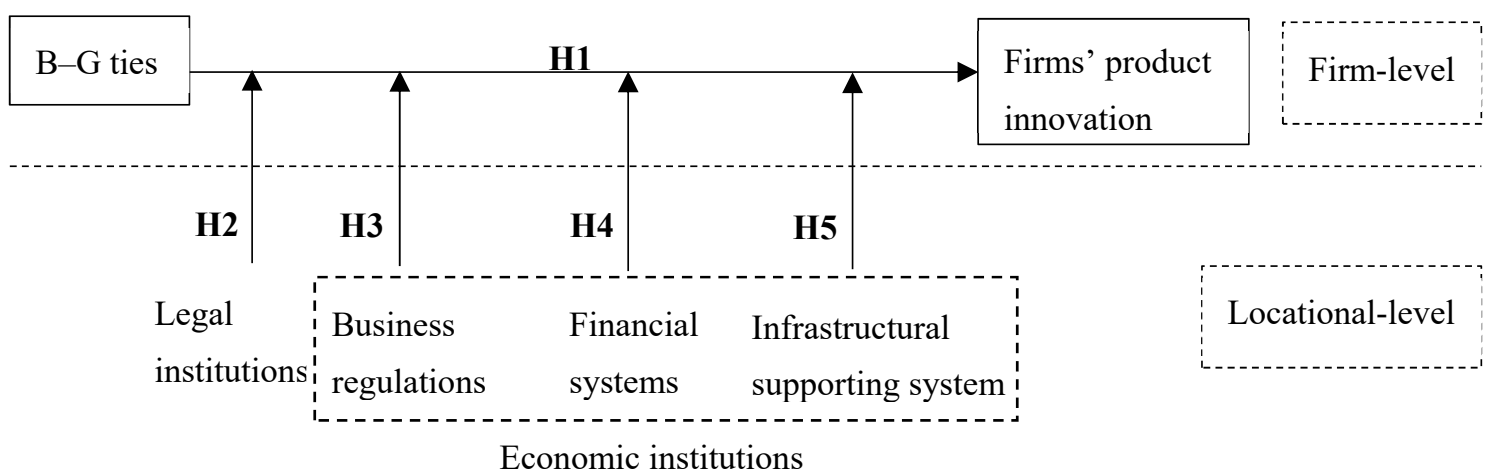

Figure 1. Hypotheses' position. B-G: Business-government, H: Hypothesis.

\section{Data and Methods}

\subsection{Data}

This study uses data from the China Enterprise Survey 2012 (CES) of the World Bank Enterprise Surveys (www.enterprisesurveys.org). Using a stratified sampling method, the CES collects firm-level data from 25 cities in China. The survey covers a sample of state-owned, manufacturing, and service firms. These sampled cities involve Hefei, Beijing, Guangzhou, Shenzhen, Foshan, Dongguan, Shijiazhuang, Tangshan, Zhengzhou, Luoyang, Wuhan, Nanjing, Wuxi, Suzhou, Nantong, Shenyang, Dalian, Jinan, Qingdao, Yantai, Shanghai, Chengdu, Hangzhou, Ningbo, and Wenzhou. The CES collects data focusing on the following aspects: Firm general information, infrastructure and services, sales and suppliers, the degree of competition, capacity, land and permits, crime, innovation and technology, finance, business-government relations, labor, and performance [34]. Particularly, the CES data comprise information concerning business-government ties, which is appropriate for this study's research purpose. To fit this study's end, service firms and state-owned enterprises (SOEs) are excluded from the data sample. Private firms have to invest in building and maintaining B-G ties [38], which change in time, while SOEs' existential basis is a strong and enduring B-G tie, which remains stable. SOEs are therefore excluded from the sample. Moreover, manufacturing firms are more product-innovation-oriented than service firms [80]. Additionally, in comparison to service firms, manufacturing firms provide complete records on innovation-related items, especially on product innovation. Furthermore, an exclusive focus on manufacturing firms helps to control for external effects arising from business sectors or industry environments [2]. A total of 1692 observations within 25 cities finally constitute the dataset.

\subsection{Measures}

Firms' product innovation is the dependent variable. A firm is identified as conducting product innovation if it introduces new products into the market $[14,81,82]$. The survey asks respondents about the percentage of annual sales that is arising from new products that are introduced in the last three years (see Appendix A: Table A1). This study multiplies this rate by firm annual sales to obtain the amount of annual product innovation. To be consistent with previous studies, this study uses the logarithm of new product sales to represent firms' product innovation.

$B-G$ ties are the independent variable. B-G ties refer to personal or organizational linkages between firms and public authorities [7]. The study identifies firms' $B-G$ ties as senior managers interacting with government officials for dealing with business or regulation issues [9,72]. Consistent with Zhang et al. [72], this study measures the B-G ties by investigating the time that a senior manager invests in business-government interactions [7,9]. This measure is available from the CES data through the following question: "In a typical week over the last year, what percentage of total senior 
management's time was spent on dealing with requirements imposed by government regulations?" (see Appendix A: Table A1). It takes a value range from 0 to 100\%. The response to this question showed an uneven distribution: $51 \%$ of the senior managers invested no time in $B-G$ ties. The mean percentage of time invested in $\mathrm{B}-\mathrm{G}$ ties is 1.29 , and $\mathrm{SD}$ is 3.0. In addition, the mean percentage of time spent on $B-G$ ties also varies significantly across cities $(F=13.17, p<0.001)$. These results show that the time senior managers spent varied significantly across firms and cities, which indicates that time and energy investment in interactions with officials can be a proxy for B-G ties [72]. The general relationship between product innovation and B-G ties is presented in Table 1.

Table 1. Descriptive statistics for firms' product innovation and B-G ties.

\begin{tabular}{|c|c|c|c|c|}
\hline & & \multicolumn{2}{|c|}{ Product Innovation } & \multirow{2}{*}{ Total } \\
\hline & & Yes & No & \\
\hline \multirow{3}{*}{ B-G ties } & Yes & $433(26 \%)$ & $396(23 \%)$ & 829 \\
\hline & No & $344(20 \%)$ & $519(31 \%)$ & 863 \\
\hline & & 777 & 915 & 1692 \\
\hline
\end{tabular}

This study measures the development status of specific institutional components as follows: Legal institutions. The CES questionnaire uses Likert scales to measure the perceptions of managers on the development of regional institutions. The CES provides two items to collect information on the development of the legal institutions of the surveyed cities that host firms. Using a four-point scale $(1=$ strongly disagree, $4=$ strongly agree), the questionnaire surveyed senior managers to what extent they agree "the court system is fair, impartial and uncorrupted". In addition, the survey asked the senior managers to what degree the court is an obstacle to the firm's operation with a five-point scale $(0=$ no obstacle and $4=$ very severe obstacle) (see Appendix A: Table A1). To get a consistent measurement, this study inversed the measurement scale of the second item $(0=$ very severe obstacle and $4=$ no obstacle). The level of theoretical interest is the regional institutional level, which led to multilevel effects being this study's key focus. Therefore, it was needed to combine these two measures into an overall indicator to indicate the development of regional legal institutions. To be consistent with recommendations of multilevel researchers [83], this study first assessed the interrater reliability using the intraclass correlations (i.e., ICC(1) and ICC(2)). The acceptable levels of these two assessments $(\operatorname{ICC}(1)=0.112, \operatorname{ICC}(2)=0.893)$ indicate that it is reasonable to aggregate these two measures to a single score for each city.

Business regulations. Three five-point scale items of the questionnaire asked respondents to indicate to what extent the business regulations, i.e., tax rates, tax administration, and business licensing and permits, are obstacles to their firms' operations $(0=$ no obstacle and $4=$ very severe obstacle) (see Appendix A: Table A1). To ease the understanding of the results, this study firstly reversed them (i.e., $0=$ very severe obstacle, $4=$ no obstacle). Then, it aggregated these items at the city level to measure the development of regional business regulations $(\operatorname{ICC}(1)=0.494, \operatorname{ICC}(2)=0.985)$. This measure broadly captures the development status of the regional business regulations.

Financial systems. In the CES, the respondents are expected to answer the question that concerns the extent to which they perceive obstacles in getting access to financial capital $(0=$ no obstacle and 4 = very severe obstacle) (see Appendix A: Table A1). To ease the understanding of the results, this study first reversed this item (i.e., $0=$ very severe obstacle and $4=$ no obstacle). Then, it aggregated it at the city level to measure the development of financial systems within subnational regions (ICC $(1)=0.228$, $\operatorname{ICC}(2)=0.952)$.

Infrastructural supporting systems. The survey also provides information to identify the quality of the infrastructural services that are provided by local markets and governments. Using two five-point scale items, the CES asked senior managers to what extent they perceived (limited) access to electricity and telecommunications as obstacles to business activities $(0=$ no obstacle and $4=$ very 
severe obstacle) (see Appendix A: Table A1). To obtain a straight understanding of the results, this study first reversed this item (i.e., $0=$ very severe obstacle and $4=$ no obstacle). Then, it aggregated these data at the city level to indicate the development status of the regional infrastructural supporting systems $(\operatorname{ICC}(1)=0.187, \operatorname{ICC}(2)=0.940)$.

In the literature, other measures are also used to capture the institutional development at different levels. For example, Fan's index measures the provincial-level institutional development in China [84]; and Gaur and Lu's measures concentrate on the country-level difference of institutional development that is based on the World Competitiveness Yearbook (1991-2001) [85]. This paper focuses on the subprovincial level institutions in China. However, there are no appropriate measures for this research focus. Therefore, building on the CES data, this study develops composite constructs to measure the institutional developments at the city level [86]. The considerations for this composite approach are as follows. First, aggregated constructs from perception-based data can be as reliable as the objective measures [87]. Second, due to the latent nature of the institutions, a composite measure that involves information from several aspects of the institution is judged better to capture the institution qualities [86]. Thus, this study uses firm-level perception data of institution developments to construct city-level measures of institutional components. The ICC checks indicate that this study's aggregated constructs are validated proxies for regional institutional components.

Control variables. In addition to institutional elements, firms' characteristics and industrial factors may influence firms' product innovation, as the "strategy tripod" perspective argues [24]. To obtain unbiased results, this study needs to control these potential firm- and industry-level effects. Firm size is defined as the total number of employees $[15,88,89]$. Managerial experience is defined as how many years the senior managers have worked in this sector [60]. Employee training represents whether or not the firm has formal training programs for full-time employees, which takes 1 if yes and 0 otherwise. Employees' education is defined as the average education years of a firm's employees [72]. The annual sales of the firms are also included in the model as a control factor $[38,72,89]$. Additionally, industrial competition indicates whether or not the firm competes with informal companies, which takes 1 for yes and 0 otherwise. In addition, this study includes industry dummies to control effects arising from the industry. Last, we include R\&D intensity into models to perform a robustness test.

\subsection{Analytical Approach}

The study employed multilevel modeling to test the hypotheses. Firms are nested in cities, which means that the data are of a hierarchical nature with two levels: The level of the firm (level 1) and the level of the city (level 2). Previous studies have predominantly implemented ordinary linear regression to analyze the influence of institutions on firm performance, although they highlighted the variant among provinces, states, or cities [15]. Statistically, in the nested data, the residuals at the firm level correlate with the residuals at the city level, which violates the independent and identically distributed assumption of the linear regression [90]. In other words, employing linear regression techniques to examine the nested data would obtain biased estimates. Thus, to this study's research purpose, multilevel modeling was a more appropriate method $[15,91]$ that allowed to estimate both firms- and city-level variance in firm innovation [90]. Clearly, variables concerning the development of regional institutions are this study's city-level measures.

To alleviate multicollinearity caused by the correlation between intercepts and slops [92], this study centered level-1 and level-2 predictors at their grand mean separately when the direct effect of firms' B-G ties on firms' product innovation was examined. Particularly, it centered level-1 predictors at group mean and level-2 factors at grand mean when the cross-level effects were examined $[93,94]$. 


\section{Results}

\subsection{Descriptive Statistics}

Table 2 summarizes the means, standard deviations, and minimum and maximum values of the variables. It is observed that the percentage of weekly time of senior managers spent on building and maintaining B-G ties is $1.29 \%$ at the mean, and 35\% at maximum. Regarding institutional components, the differentiated standard deviations indicate that their development levels vary significantly among sampled cities. The development of the legal institutions (Mean $=3.19, \mathrm{SD}=0.16$ ) and infrastructural supporting systems (Mean $=3.57, \mathrm{SD}=0.27$ ) shows less variance in comparison with the financial systems $($ Mean $=3.17, \mathrm{SD}=0.42$ ) and business regulations (Mean =3.33, SD =0.54). Table 3 shows the correlations matrix of all variables in this study. As discussed, the correlation between B-G ties and firms' product innovation presents the expected sign. All variance inflation factors (VIFs) are below 5, which illustrates that multicollinearity among variables is not a severe concern of our study.

Table 2. Descriptive statistics.

\begin{tabular}{|c|c|c|c|c|c|}
\hline Variable & Obs. & Mean & SD & Min & Max \\
\hline Firms' product innovation (log) & 1645 & 6.89 & 7.81 & 0 & 23.61 \\
\hline B-G ties & 1622 & 1.29 & 3.0 & 0 & 35 \\
\hline Manager experience & 1666 & 2.72 & 0.49 & 0 & 3.85 \\
\hline Competition & 1604 & 0.50 & 0.50 & 0 & 1 \\
\hline Employee education & 1655 & 10.18 & 1.88 & 1 & 18 \\
\hline Employee training & 1692 & 0.86 & 0.35 & 0 & 1 \\
\hline Firm size (log) & 1692 & 4.44 & 1.29 & 1.61 & 10.31 \\
\hline Annual sale (log) & 1692 & 16.91 & 1.67 & 11.51 & 24.41 \\
\hline Industry & 1692 & 25 & 5.83 & 15 & 37 \\
\hline R\&D intensity & 1586 & 0.20 & 0.06 & 0 & 0.79 \\
\hline Infrastructural supporting system & 25 & 3.57 & 0.27 & 2.82 & 3.97 \\
\hline Business regulations & 25 & 3.33 & 0.54 & 1.89 & 3.88 \\
\hline Financial systems & 25 & 3.17 & 0.42 & 2.21 & 3.74 \\
\hline Legal institutions & 25 & 3.19 & 0.16 & 2.76 & 3.43 \\
\hline
\end{tabular}


Table 3. The Pearson correlations between the variables and variance inflation factors (VIFs)

\begin{tabular}{|c|c|c|c|c|c|c|c|c|c|c|c|c|c|c|c|c|c|c|}
\hline & 1 & 2 & 3 & 4 & 5 & 6 & 7 & 8 & 9 & 10 & 11 & 12 & 13 & 14 & 15 & 16 & 17 & 18 \\
\hline 1. Firms' product innovation & 1 & & & & & & & & & & & & & & & & & \\
\hline $\begin{array}{l}\text { 2. B-G ties (BGT) } \\
\text { 3. Infrastructural supporting system (ISS) }\end{array}$ & $\begin{array}{c}0.18^{*} \\
-0.14^{*}\end{array}$ & $\begin{array}{c}1 \\
0.01\end{array}$ & 1 & & & & & & & & & & & & & & & \\
\hline $\begin{array}{l}\text { 3. Infrastructural supporting system (ISS) } \\
\text { 4. Business regulations (BR) }\end{array}$ & $\begin{array}{l}-0.1{ }^{*} \\
-0.23\end{array}$ & 0.01 * & $0.32 *$ & 1 & & & & & & & & & & & & & & \\
\hline $\begin{array}{l}\text { 4. Business regulations (BK) } \\
\text { 5. Financial systems (FS) }\end{array}$ & $\begin{array}{l}-0.23 \\
-0.09 * \\
\end{array}$ & 0.04 & $-0.25 *$ & $0.41 *$ & 1 & & & & & & & & & & & & & \\
\hline 6. Legal institutions (LI) & -0.02 & $0.06^{*}$ & $0.08^{*}$ & 0.46 * & $0.08 *$ & 1 & & & & & & & & & & & & \\
\hline 7. Manager experience & $0.10^{*}$ & -0.03 & 0.08 * & $-0.19 *$ & $-0.20 *$ & $-0.05 *$ & 1 & & & & & & & & & & & \\
\hline $\begin{array}{l}\text { 8. Competition } \\
\text { 8. }\end{array}$ & $0.16 *$ & $0.09 *$ & 0.04 & -0.14 * & $-0.29 *$ & 0.01 & 0.02 & 1 & & & & & & & & & & \\
\hline 9. Education & $0.07 *$ & 0.08 * & $0.06 *$ & $0.15 *$ & $0.14 *$ & 0.01 & 0.04 & -0.07 * & 1 & & & & & & & & & \\
\hline 10. Training & $0.16^{*}$ & 0.04 & -0.002 & $0.09 *$ & $0.12 *$ & 0.04 & -0.03 & -0.06 * & 0.04 & 1 & & & & & & & & \\
\hline 11. Firm size & 0.25 * & $0.09 *$ & -0.05 & $-0.06 *$ & 0.01 & $-0.08^{*}$ & $0.16^{*}$ & $-0.09 *$ & 0.06 * & 0.21 * & 1 & & & & & & & \\
\hline 12. Annual sale & $0.27 *$ & $0.08 *$ & -0.04 & -0.05 * & -0.01 & $-0.07 *$ & $0.20 *$ & -0.09 * & 0.11 * & 0.19 * & $0.61 *$ & 1 & & & & & & \\
\hline 13. Industry & $0.05 *$ & -0.001 & -0.03 & -0.03 & 0.01 & -0.05 & 0.01 & $-0.08 *$ & 0.15 * & 0.03 & 0.02 & 0.09 * & 1 & & & & & \\
\hline 14. R\&D intensity & $0.25 *$ & $0.24 *$ & $-0.10 *$ & 0.01 & $\begin{array}{l}0.01 \\
-0.02\end{array}$ & 0.01 & $-0.07 *$ & 0.11 * & 0.11 * & 0.05 * & 0.01 & -0.05 & $\begin{array}{c}1 \\
0.04\end{array}$ & 1 & & & & \\
\hline 15. $\mathrm{BGT} \times \mathrm{LI}$ & $-0.10 *$ & $-0.07 *$ & $0.06^{*}$ & $0.08^{*}$ & 0.04 & -0.06 * & 0.01 & -0.09 * & 0.04 & 0.07 * & 0.03 & 0.04 & -0.03 & $\begin{array}{l}1 \\
-0.02\end{array}$ & 1 & & & \\
\hline 16. $\mathrm{BGT} \times \mathrm{BR}$ & 0.03 & $0.05 *$ & $0.13 *$ & 0.04 & 0.14 * & $0.09^{*}$ & 0.03 & -0.03 & $0.13 *$ & $0.10^{*}$ & 0.01 & $0.07 *$ & -0.04 & $0.07^{*}$ & $0.45^{*}$ & 1 & & \\
\hline 17. $\mathrm{BGT} \times \mathrm{FS}$ & -0.01 & 0.14 * & 0.44 * & $0.14 *$ & 0.27 * & 0.04 & $0.06 *$ & 0.14 * & $0.05 *$ & -0.04 & $-0.05 *$ & -0.03 & -0.04 & 0.16 * & 0.04 & $0.43 *$ & 1 & \\
\hline 18. BGT $\times$ ISS & 0.02 & 0.22 * & 0.04 & $0.12 *$ & $0.39 *$ & $0.06^{*}$ & -0.10 * & $-0.11 *$ & 0.01 & 0.14 * & 0.02 & 0.01 & -0.03 & 0.18 * & $0.08^{*}$ & 0.44 * & $0.02 *$ & 1 \\
\hline VIFs & & 1.20 & 1.71 & 2.57 & 2.39 & 1.45 & 1.14 & 1.16 & 1.14 & 1.10 & 2.58 & 2.65 & 1.06 & 1.21 & 1.43 & 2.69 & 2.15 & 1.79 \\
\hline
\end{tabular}




\subsection{Regression Results}

Regression results are reported in Table 4. Column 1 presents the null model of the multilevel linear model, which indicates that $20.25 \%$ of the variance is attributable to the city-level $\left(\operatorname{Var}\left(\_c o n s\right)=12.44, \operatorname{Var}(\right.$ Residual $\left.)=49.0\right)$. This result supports the use of multilevel modeling. To test Hypothesis 1, Model 2 is run; it examines the direct influence of B-G ties on firms' product innovation. The significant coefficient of B-G ties illustrates that, after controlling city-, industry-, and firm-level effects, $\mathrm{B}-\mathrm{G}$ ties are significantly conducive for improving firms' product innovation $(\beta=1.214, p<0.01)$. Obviously, Hypothesis 1 has been corroborated.

Table 4. Results of multilevel regression analysis.

\begin{tabular}{|c|c|c|c|c|c|c|}
\hline Variables & Model 1 & Model 2 & Model 3 & Model 4 & Model 5 & Model 6 \\
\hline Intercept & $\begin{array}{l}7.27^{* * *} \\
(0.729)\end{array}$ & $\begin{array}{c}7.855^{* * *} \\
(0.854)\end{array}$ & $\begin{array}{c}7.835^{* * *} \\
(0.852)\end{array}$ & $\begin{array}{c}7.852 * * * \\
(0.855)\end{array}$ & $\begin{array}{c}7.840 * * * \\
(0.852)\end{array}$ & $\begin{array}{c}7.816^{* * *} \\
(0.853)\end{array}$ \\
\hline \multicolumn{7}{|l|}{ Level 1} \\
\hline B-G ties (BGT) (H1) & & $\begin{array}{c}1.214^{* * *} \\
(0.30)\end{array}$ & $\begin{array}{c}1.271 * * * \\
(0.301)\end{array}$ & $\begin{array}{c}1.159 * * * \\
(0.312)\end{array}$ & $\begin{array}{c}1.060 * * * \\
(0.307)\end{array}$ & $\begin{array}{c}1.404^{* * *} \\
(0.314)\end{array}$ \\
\hline Manager experience & & $\begin{array}{c}0.888^{* *} \\
(0.375)\end{array}$ & $\begin{array}{c}0.890 * * \\
(0.375)\end{array}$ & $\begin{array}{c}0.877^{* *} \\
(0.376)\end{array}$ & $\begin{array}{c}0.862 * * \\
(0.375)\end{array}$ & $\begin{array}{c}0.859 * * \\
(0.375)\end{array}$ \\
\hline Employee education & & $\begin{array}{c}0.315^{* * *} \\
(0.107)\end{array}$ & $\begin{array}{c}0.286^{* * *} \\
(0.108)\end{array}$ & $\begin{array}{c}0.319^{* * *} \\
(0.108)\end{array}$ & $\begin{array}{c}0.322 * * * \\
(0.107)\end{array}$ & $\begin{array}{c}0.307^{* * *} \\
(0.107)\end{array}$ \\
\hline Employee training & & $\begin{array}{c}1.772 \text { *** } \\
(0.539)\end{array}$ & $\begin{array}{c}1.795^{* * *} \\
(0.538)\end{array}$ & $\begin{array}{c}1.786^{* * *} \\
(0.540)\end{array}$ & $\begin{array}{c}1.826^{* * *} \\
(0.539)\end{array}$ & $\begin{array}{c}1.753^{* * *} \\
(0.539)\end{array}$ \\
\hline Firm size & & $\begin{array}{l}0.408 * \\
(0.213)\end{array}$ & $\begin{array}{l}0.389 * \\
(0.213)\end{array}$ & $\begin{array}{l}0.416 * \\
(0.213)\end{array}$ & $\begin{array}{c}0.419 * * \\
(0.213)\end{array}$ & $\begin{array}{c}0.429 * * \\
(0.213)\end{array}$ \\
\hline Annual sale & & $\begin{array}{l}0.791^{* * *} \\
(0.168)\end{array}$ & $\begin{array}{l}0.816^{* * *} \\
(0.168)\end{array}$ & $\begin{array}{l}0.785^{* * *} \\
(0.168)\end{array}$ & $\begin{array}{c}0.799 * * * \\
(0.168)\end{array}$ & $\begin{array}{c}0.772^{* * *} \\
(0.168)\end{array}$ \\
\hline Competition & & $\begin{array}{c}1.559 * * * \\
(0.379)\end{array}$ & $\begin{array}{c}1.546^{* * *} \\
(0.379)\end{array}$ & $\begin{array}{c}1.552 * * * \\
(0.380)\end{array}$ & $\begin{array}{c}1.501 * * * \\
(0.380)\end{array}$ & $\begin{array}{c}1.516^{* * *} \\
(0.380)\end{array}$ \\
\hline Industry & & Yes & Yes & Yes & Yes & Yes \\
\hline \multicolumn{7}{|l|}{ Level 2} \\
\hline Legal institutions (LI) & & $\begin{array}{c}1.193 \\
(4.572)\end{array}$ & $\begin{array}{c}1.054 \\
(4.556)\end{array}$ & $\begin{array}{c}1.209 \\
(4.575)\end{array}$ & $\begin{array}{c}1.163 \\
(4.562)\end{array}$ & $\begin{array}{c}1.213 \\
(4.566)\end{array}$ \\
\hline Business regulations (BR) & & $\begin{array}{c}-3.063 * \\
(1.732)\end{array}$ & $\begin{array}{c}-3.096 \text { * } \\
(1.726)\end{array}$ & $\begin{array}{c}-3.058^{*} \\
(1.733)\end{array}$ & $\begin{array}{c}-3.063 * \\
(1.728)\end{array}$ & $\begin{array}{c}-3.070 \text { * } \\
(1.730)\end{array}$ \\
\hline Financial systems (FS) & & $\begin{array}{c}0.084 \\
(1.973) \\
\end{array}$ & $\begin{array}{c}0.138 \\
(1.966)\end{array}$ & $\begin{array}{c}0.079 \\
(1.974)\end{array}$ & $\begin{array}{c}0.084 \\
(1.968)\end{array}$ & $\begin{array}{c}0.075 \\
(1.970) \\
\end{array}$ \\
\hline $\begin{array}{c}\text { Infrastructural } \\
\text { supporting systems (ISS) }\end{array}$ & & $\begin{array}{l}-2.223 \\
(2.778)\end{array}$ & $\begin{array}{l}-2.160 \\
(2.768)\end{array}$ & $\begin{array}{l}-2.226 \\
(2.779)\end{array}$ & $\begin{array}{l}-2.201 \\
(2.771)\end{array}$ & $\begin{array}{l}-2.236 \\
(2.774)\end{array}$ \\
\hline \multicolumn{7}{|l|}{ Level $1 \times$ Level 2} \\
\hline $\mathrm{BGT} \times \mathrm{LI}(\mathrm{H} 2)$ & & & $\begin{array}{l}-4.438^{* *} \\
(2.035)\end{array}$ & & & \\
\hline $\mathrm{BGT} \times \mathrm{BR}(\mathrm{H} 3)$ & & & & $\begin{array}{c}0.387 \\
(0.607)\end{array}$ & & \\
\hline $\mathrm{BGT} \times \mathrm{FS}(\mathrm{H} 4)$ & & & & & $\begin{array}{l}1.886^{* *} \\
(0.80)\end{array}$ & \\
\hline BGT × ISS (H5) & & & & & & $\begin{array}{l}-2.263^{* *} \\
(1.108)\end{array}$ \\
\hline
\end{tabular}

Standard errors in parentheses; ${ }^{* * *} p<0.01,{ }^{* *} p<0.05,{ }^{*} p<0.1$.

To alleviate the collinearity arising from the interdependence of institutional components, the interaction variables are included into models separately. Models 3-6 present results that indicate to what extent the institutional components shape the value of $B-G$ ties on firms' product innovation. Model 3 examines the contingent effects of legal institutions on the relationship between B-G ties and firms' product innovation. As predicted, the interaction term shows a negative coefficient $(\beta=-4.438$, $p<0.05)$. It indicates that firms' product innovation benefits more from B-G ties when they operate in cities with less developed legal institutions. Thus, Hypothesis 2 is validated. Model 4 presents an insignificant moderation effect of the business regulations ( $\beta=0.387, p=$ n.s.), and accordingly, 
Hypothesis 3 is not confirmed. Hypothesis 4 states that the development of financial systems would decrease the value of $\mathrm{B}-\mathrm{G}$ ties in the emerging economies. As Model 5 suggests, a higher development level of financial systems amplifies the positive effect of $B-G$ ties on firms' product innovation $(\beta=1.886$, $p<0.05)$. This result rejects Hypothesis 4. From Model 6, it can be read that a higher development level of the infrastructural supporting systems lowers down the influence of $B-G$ ties on firms' product innovation $(\beta=-2.263, p<0.05)$. Therefore, the empirical findings confirm $\mathrm{H} 1, \mathrm{H} 2$, and $\mathrm{H} 5$, whereas $\mathrm{H} 3$ and $\mathrm{H} 4$ are rejected (Table 5).

Table 5. The results of hypothesis testing.

\begin{tabular}{l}
\hline Hypotheses \\
\hline H1: In transitional China, B-G ties have a positive effect on Chinese manufacturing firms' product innovation. \\
\hline $\begin{array}{l}\text { H2: The effect of B-G ties on Chinese manufacturing firms' product innovation is less positive when legal institutions are } \\
\text { more developed. }\end{array}$ \\
$\begin{array}{l}\text { H3: The effect of B-G ties on Chinese manufacturing firms' product innovation is less positive when business regulations are } \\
\text { more developed. }\end{array}$ \\
$\begin{array}{l}\text { H4: The effect of B-G ties on Chinese manufacturing firms' product innovation is less positive when financial systems are } \\
\text { more developed. }\end{array}$ \\
$\begin{array}{l}\text { H5: The effect of B-G ties on Chinese manufacturing firms' product innovation is less positive when the infrastructural } \\
\text { supporting systems are more developed. }\end{array}$ \\
\hline
\end{tabular}

To obtain a detailed and vivid understanding of the contingent effect of the institutional components, this study plots predictive margins of the interaction effects that are presented in Model 3,5 , and 6 of Table 4. Figure 2 displays the support for the prediction of $\mathrm{H} 2$. In cities with a lower development level (e.g., -1 S.D.) of legal institutions, a higher degree (e.g., +1 S.D.) of B-G ties leads to a higher product innovation. Similarly, firms with a lower degree (e.g., -1 S.D.) of B-G ties significantly benefit more if they operate in cities with a higher development level of legal institutions. Figure 3 demonstrates that the positive effect of B-G ties on firms' product innovation is further reinforced when financial systems are more developed. Specifically, in cities with a higher developmental level (e.g., +1 S.D.) of financial systems, firms obtain more from product innovation when they invest more in B-G ties. This significant result is inconsistent with H4. Figure 4 supports the prediction of H5. In cities with a higher development level (e.g., +1 S.D.) of the infrastructural supporting systems, a lower degree of B-G ties (-1 S.D.) significantly improves firms' product innovation. Further, as the infrastructural supporting systems improve, the benefits arising from a higher degree (e.g., +1 S.D.) of B-G ties decrease sharply. Overall, specific components of the institutions shape the effect of B-G ties on firms' product innovation to varying extents within subnational regions of transitional China. In addition, a simplified graph is plotted to present how B-G ties influence firms' product innovation in specific institutional environments. As shown in Figure 5, firms harvest more from product innovation when they invest more in B-G ties (e.g., +1 S.D.) no matter the extent to which the institutions develop. This evidence reveals that the value of stronger $B-G$ ties for innovation is more significant than weaker B-G ties in transitional China. 


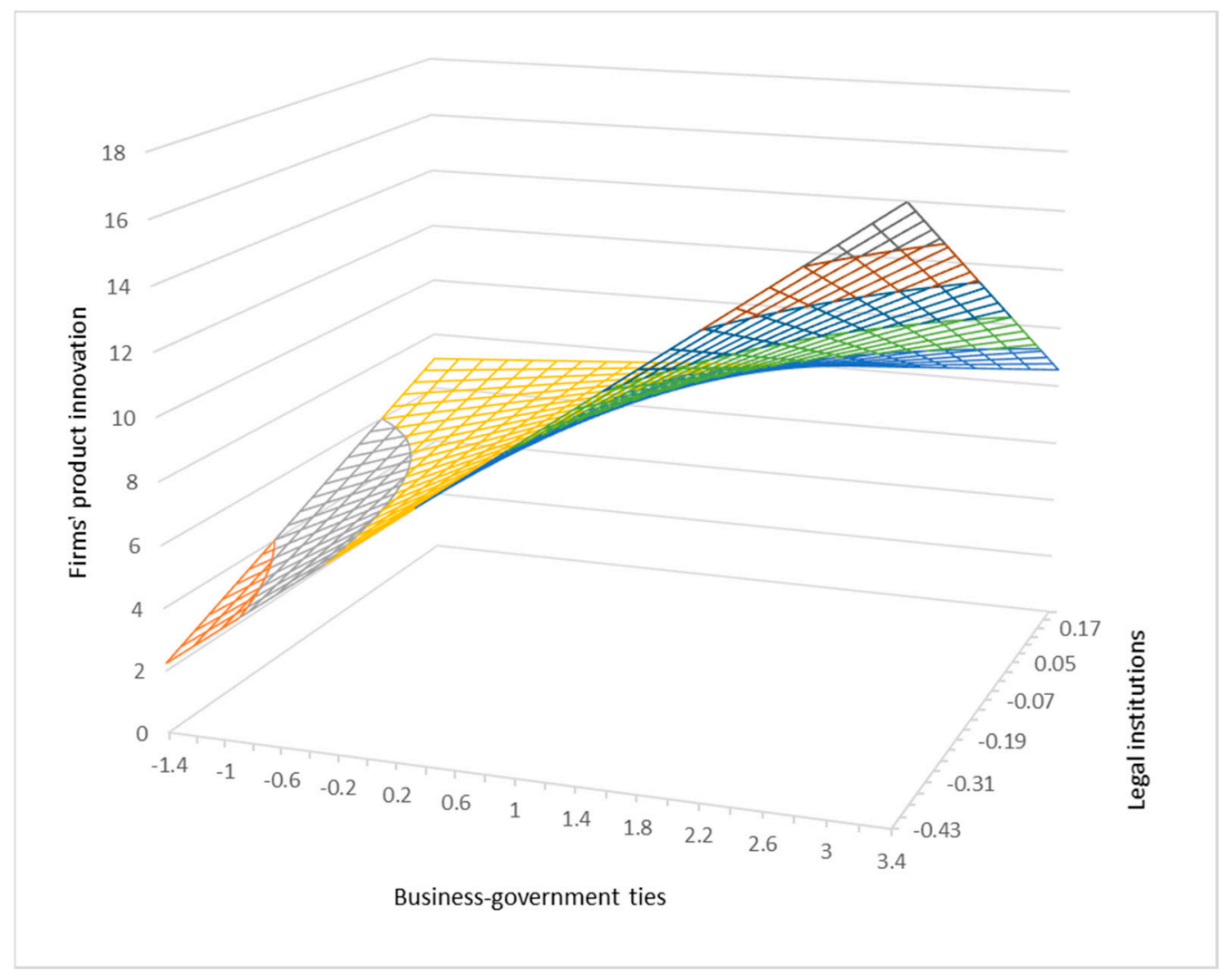

Figure 2. The contingent effects of legal institutions.

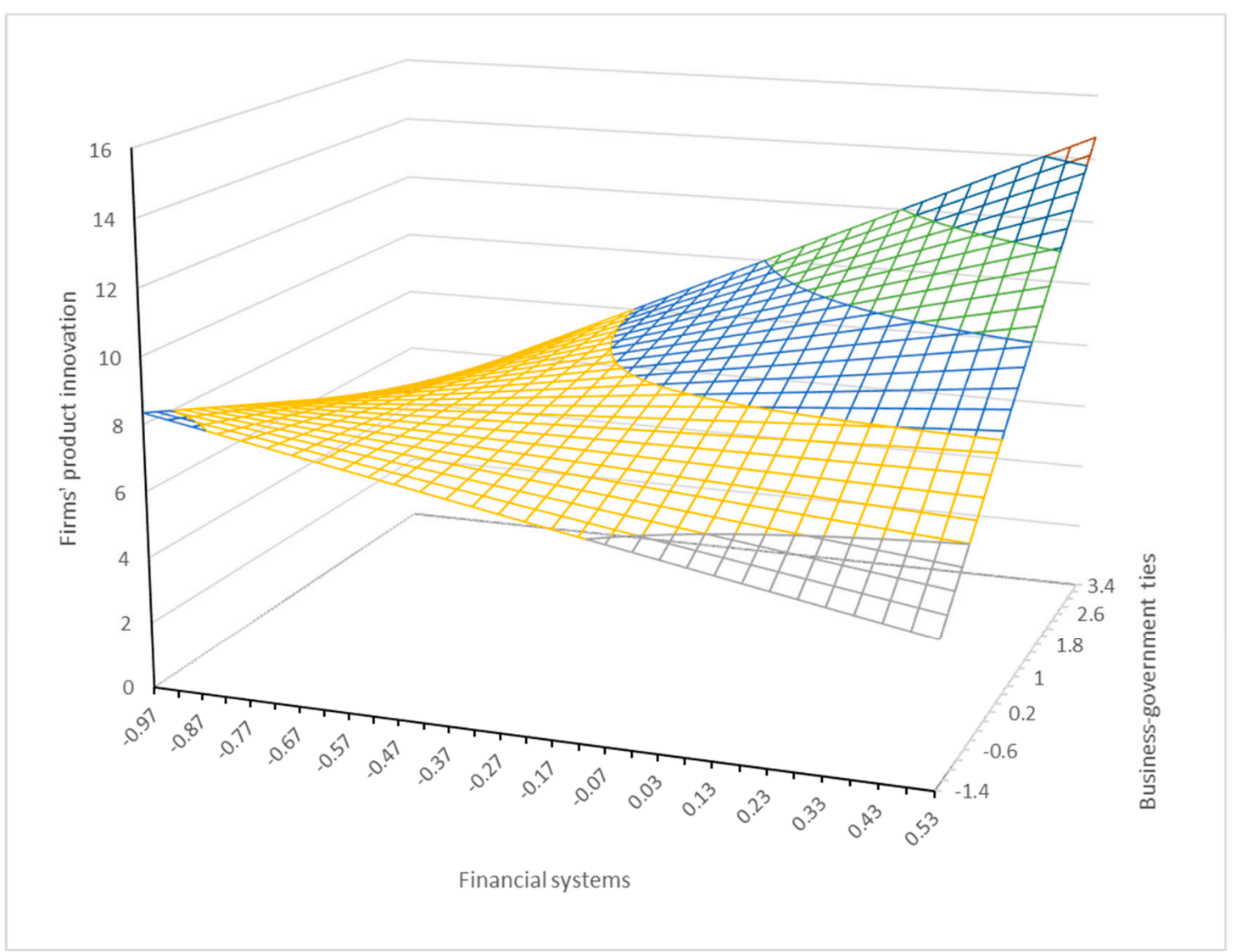

Figure 3. The contingent effects of financial systems. 


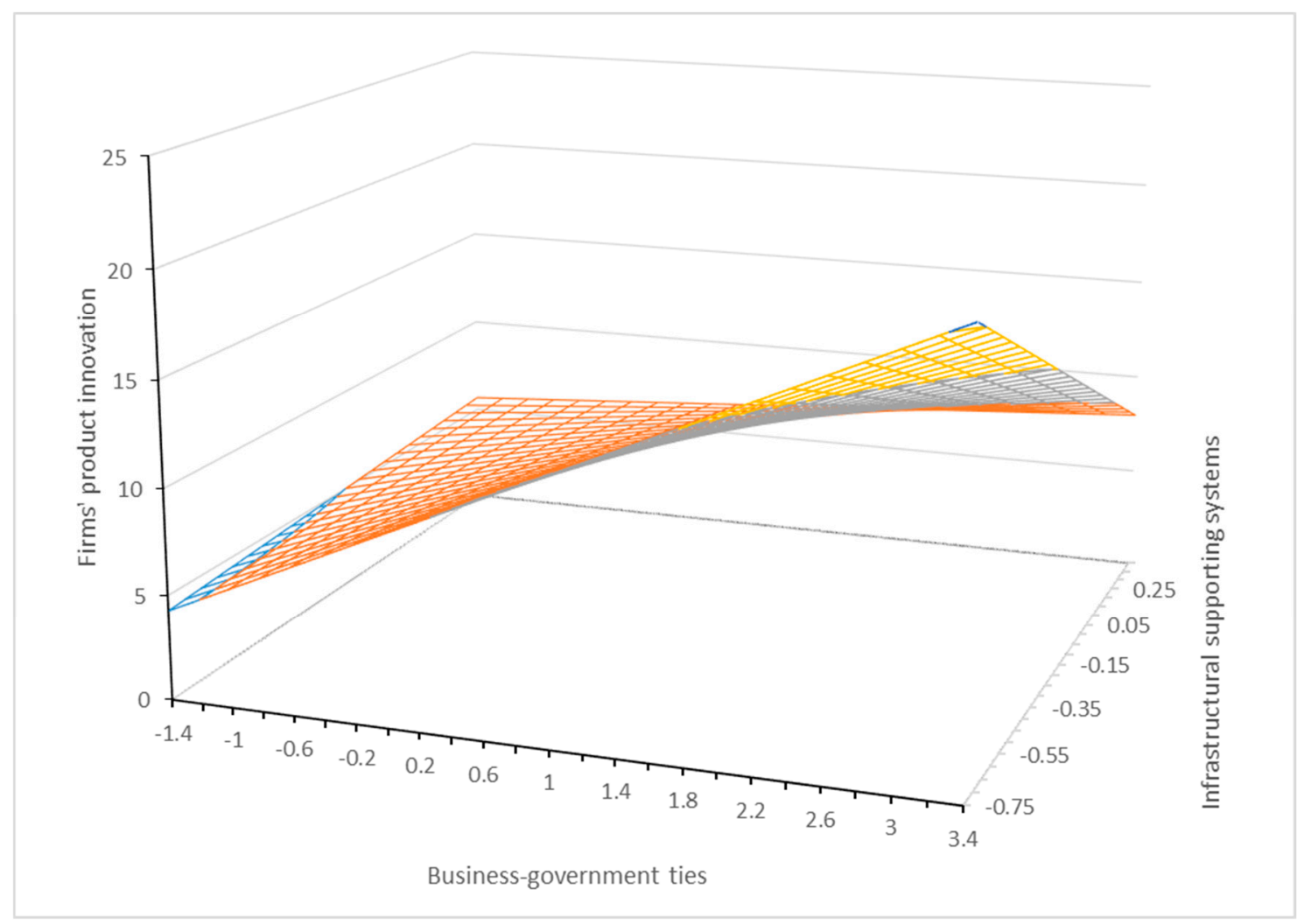

Figure 4. The contingent effects of infrastructural supporting systems.

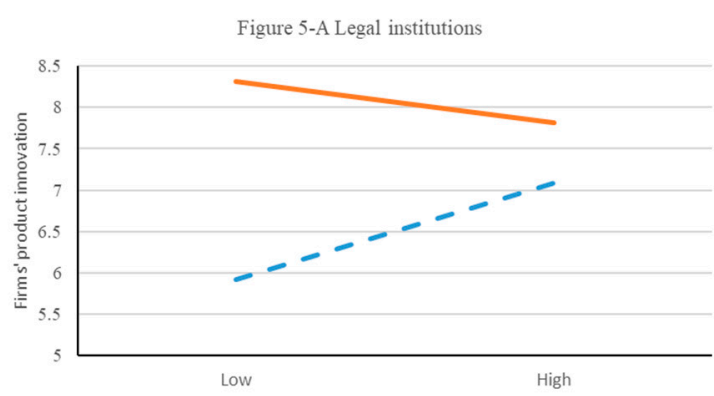

- Low B-G ties (-1 S.D) — High B-G ties (+1 S.D)

Figure 5-C Infrastructural supporting systems

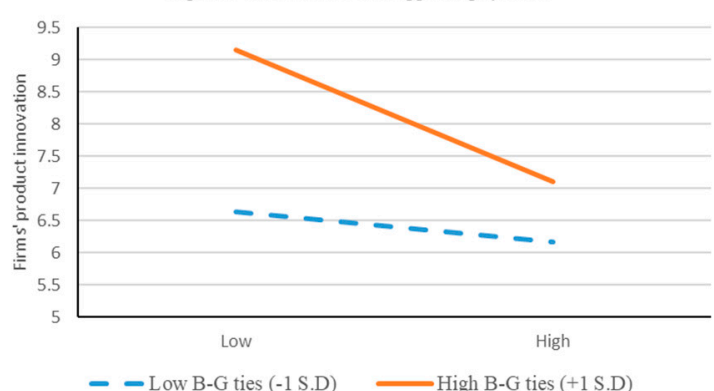

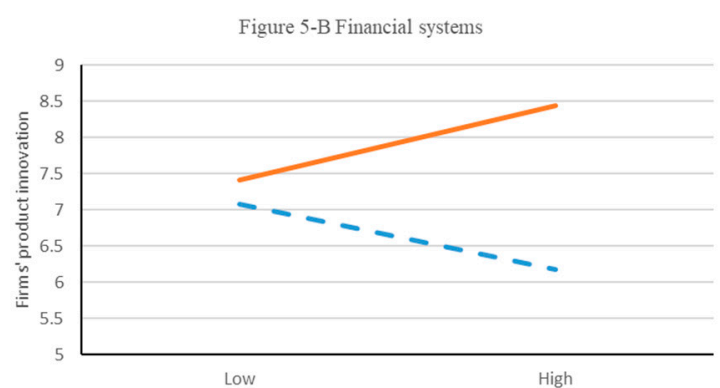

- L Low B-G ties (-1 S.D) — High B-G ties (+1 S.D)

Figure 5. The effects of B-G ties on firms' product innovation depend on institution components.

Last, we conducted several robustness checks. Firstly, a new independent variable was included into the models: Firms' R\&D intensity (the ratio of R\&D expenditure to firm annual sales), which is reported to have a substantial effect on firms' product innovation [16,95]. This study's conclusions (see Table 6) remain. Secondly, this study also controlled for the potential nonlinear effect of the business-government interaction that is reported to be a determinant of firms' innovation 
performance [17]. To this end, the study includes the squared term of B-G ties into the models. The results are in line with Table 4, and the coefficients of the squared terms are insignificant (see Table 7). Thirdly, clustering standard errors were used at the subnational city level to consider the effects arising from the potential correlation between firm-level and city-level observations. The discussed results (see Table 8) remain. Fourthly, building on Models 2-6 of Table 4, the study treats the group means of the level- 1 factors as level- 2 controls, and then adds them into the models to confirm whether or not the cross-level interactions are spurious, as Hofmann and Gavin recommend [94]. As expected, the estimates' significance and influence directions remain consistent (see Table 9). Fifthly, to alleviate the effects arising from the industries (e.g., some industries are more innovative than other industries), this study standardized the product innovation measure relative to the industry average. The results are consistent with Table 4 (see Table 10). Sixthly, we used the Heckman model to test whether or not our results were biased by sample selections. The insignificant coefficients of Lambda of Heckman two-stage model suggest that our discussed results were not driven by selection bias (see Table 11). Lastly, the propensity score matching method was used to generate a comparable sample of B-G-ties-connected firms and non-B-G-ties-connected firms. First, a fixed effects logit model was estimated [96] with variables of manager experience, employee education, employee training, firm size, firm age, firm R\&D investment, competition, and institutional components. Then, the propensity score was used to conduct two-to-one matching and we obtain 254 matched B-G ties and non-B-G ties firms over 24 cities. Then, a rerun of the model was done, which showed consistent significance and influence direction as discussed (see Table 12).

Table 6. Robustness check: Including R\&D intensity.

\begin{tabular}{|c|c|c|c|c|c|}
\hline Variables & Model 1 & Model 2 & Model 3 & Model 4 & Model 5 \\
\hline B-G ties & $\begin{array}{l}1.05^{* * *} \\
(0.301)\end{array}$ & $\begin{array}{c}1.115^{* * * *} \\
(0.302)\end{array}$ & $\begin{array}{l}1.01 * * * \\
(0.312)\end{array}$ & $\begin{array}{c}0.948 * * * \\
(0.306)\end{array}$ & $\begin{array}{c}1.279 * * * \\
(0.313)\end{array}$ \\
\hline B-G ties $\times$ Legal institutions & & $\begin{array}{l}-4.161^{* *} \\
(2.016)\end{array}$ & & & \\
\hline B-G ties $\times$ Business regulations & & & $\begin{array}{c}0.316 \\
(0.597)\end{array}$ & & \\
\hline B-G ties $\times$ Financial systems & & & & $\begin{array}{l}1.403 * \\
(0.78)\end{array}$ & \\
\hline $\begin{array}{l}\text { B-G ties } \times \text { Infrastructural } \\
\text { supporting systems }\end{array}$ & & & & & $\begin{array}{l}-2.776^{* *} \\
(1.104)\end{array}$ \\
\hline R\&D intensity & $\begin{array}{c}15.54^{* * *} \\
(3.10)\end{array}$ & $\begin{array}{c}15.32 * * * \\
(3.09)\end{array}$ & $\begin{array}{c}15.49^{* * *} \\
(3.10)\end{array}$ & $\begin{array}{c}15.08^{* * *} \\
(3.11)\end{array}$ & $\begin{array}{c}16.48^{* * *} \\
(3.12)\end{array}$ \\
\hline $\begin{array}{l}\text { Controls } \\
\text { Intercept }\end{array}$ & $\begin{array}{c}\text { Yes } \\
7.69 * * * \\
(0.857)\end{array}$ & $\begin{array}{c}\text { Yes } \\
7.67 \\
(0.856)\end{array}$ & $\begin{array}{c}\text { Yes } \\
7.68^{* * * *} \\
(0.857)\end{array}$ & $\begin{array}{c}\text { Yes } \\
7.67^{* * *} \\
(0.856)\end{array}$ & $\begin{array}{c}\text { Yes } \\
7.65^{* * *} \\
(0.856)\end{array}$ \\
\hline
\end{tabular}

Standard errors in parentheses; ${ }^{* * *} p<0.01,{ }^{* *} p<0.05,{ }^{*} p<0.1$.

Table 7. Robustness check: Controlling the squared term of B-G ties.

\begin{tabular}{|c|c|c|c|c|c|}
\hline Variables & Model 1 & Model 2 & Model 3 & Model 4 & Model 5 \\
\hline B-G ties & $\begin{array}{l}1.359^{* * *} \\
(0.350)\end{array}$ & $\begin{array}{l}1.318^{* * * *} \\
(0.350)\end{array}$ & $\begin{array}{l}1.254^{* * * *} \\
(0.362)\end{array}$ & $\begin{array}{l}1.132 * * * \\
(0.357)\end{array}$ & $\begin{array}{c}1.520 * * * \\
(0.361)\end{array}$ \\
\hline Squared B-G ties & $\begin{array}{l}-0.129 \\
(0.295)\end{array}$ & $\begin{array}{c}0.041 \\
(0.297)\end{array}$ & $\begin{array}{l}-0.055 \\
(0.295)\end{array}$ & $\begin{array}{l}-0.028 \\
(0.294)\end{array}$ & $\begin{array}{l}-0.053 \\
(0.294)\end{array}$ \\
\hline B-G ties $\times$ Legal institutions & & $\begin{array}{l}-4.545^{* *} \\
(2.085)\end{array}$ & & & \\
\hline B-G ties $\times$ Business regulations & & & $\begin{array}{c}0.410 \\
(0.616)\end{array}$ & & \\
\hline B-G ties $\times$ Financial systems & & & & $\begin{array}{l}1.988^{* *} \\
(0.811)\end{array}$ & \\
\hline $\begin{array}{l}\text { B-G ties } \times \text { Infrastructural } \\
\text { supporting systems }\end{array}$ & & & & & $\begin{array}{l}-2.520 * * \\
(1.119)\end{array}$ \\
\hline Controls & Yes & Yes & Yes & Yes & Yes \\
\hline Intercept & $\begin{array}{l}7.279 * * * \\
(0.769)\end{array}$ & $\begin{array}{l}7.314^{* * *} \\
(0.662)\end{array}$ & $\begin{array}{l}7.332 * * * \\
(0.670)\end{array}$ & $\begin{array}{c}7.333 * * * \\
(0.667)\end{array}$ & $\begin{array}{l}7.329 * * * \\
(0.668)\end{array}$ \\
\hline
\end{tabular}

Standard errors in parentheses; ${ }^{* * *} p<0.01,{ }^{* *} p<0.05,{ }^{*} p<0.1$. 
Table 8. Robustness check: Clustered robust standard error model.

\begin{tabular}{|c|c|c|c|c|c|}
\hline Variables & Model 1 & Model 2 & Model 3 & Model 4 & Model 5 \\
\hline B-G ties & $\begin{array}{c}1.282^{* * *} \\
(0.418)\end{array}$ & $\begin{array}{c}1.342^{* * *} \\
(0.411)\end{array}$ & $\begin{array}{c}1.221^{* * *} \\
(0.388)\end{array}$ & $\begin{array}{c}1.115^{* * *} \\
(0.377)\end{array}$ & $\begin{array}{c}1.489 * * * \\
(0.427)\end{array}$ \\
\hline B-G ties $\times$ Legal institutions & & $\begin{array}{l}-4.501^{*} \\
(2.405)\end{array}$ & & & \\
\hline B-G ties $\times$ Business regulations & & & $\begin{array}{c}0.413 \\
(0.534)\end{array}$ & & \\
\hline B-G ties $\times$ Financial systems & & & & $\begin{array}{l}1.991 \text { ** } \\
(0.907)\end{array}$ & \\
\hline B-G ties $\times$ Infrastructural supporting systems & & & & & $\begin{array}{c}-2.522 * \\
(1.365)\end{array}$ \\
\hline Controls & Yes & Yes & Yes & Yes & Yes \\
\hline Intercept & $\begin{array}{c}7.234 * * * \\
(0.776)\end{array}$ & $\begin{array}{c}7.328^{* * *} \\
(0.661)\end{array}$ & $\begin{array}{c}7.313 * * * \\
(0.664)\end{array}$ & $\begin{array}{c}7.323 * * * \\
(0.661)\end{array}$ & $\begin{array}{c}7.311 * * * \\
(0.663)\end{array}$ \\
\hline
\end{tabular}

Robust standard errors in parentheses; ${ }^{* * *} p<0.01,{ }^{* *} p<0.05,{ }^{*} p<0.1$.

Table 9. Robustness checks: Using group means of level-1 factors as the level-2 controls.

\begin{tabular}{|c|c|c|c|c|c|}
\hline Variables & Model 1 & Model 2 & Model 3 & Model 4 & Model 5 \\
\hline \multicolumn{6}{|l|}{ Level 1} \\
\hline B-G ties & $\begin{array}{c}1.286^{* * *} \\
(0.303) \\
\end{array}$ & $\begin{array}{c}1.348^{* * *} \\
(0.304) \\
\end{array}$ & $\begin{array}{c}1.226 * * * \\
(0.316) \\
\end{array}$ & $\begin{array}{c}1.122 * * * \\
(0.310) \\
\end{array}$ & $\begin{array}{c}1.495^{* * *} \\
(0.316) \\
\end{array}$ \\
\hline Manager experience & $\begin{array}{c}0.856^{* *} \\
(0.379)\end{array}$ & $\begin{array}{l}0.857^{* *} \\
(0.379)\end{array}$ & $\begin{array}{c}0.846^{* *} \\
(0.379)\end{array}$ & $\begin{array}{l}0.828 * * \\
(0.379)\end{array}$ & $\begin{array}{c}0.830^{* *} \\
(0.379)\end{array}$ \\
\hline Competition & $\begin{array}{c}1.412 * * * \\
(0.381) \\
\end{array}$ & $\begin{array}{c}1.404^{* * *} \\
(0.381) \\
\end{array}$ & $\begin{array}{c}1.405^{* * *} \\
(0.382) \\
\end{array}$ & $\begin{array}{c}1.355^{* * *} \\
(0.381) \\
\end{array}$ & $\begin{array}{c}1.375^{* * *} \\
(0.381) \\
\end{array}$ \\
\hline Employee education & $\begin{array}{c}0.359^{* * *} \\
(0.106)\end{array}$ & $\begin{array}{c}0.330^{* * *} \\
(0.107)\end{array}$ & $\begin{array}{c}0.364^{* * *} \\
(0.107)\end{array}$ & $\begin{array}{c}0.367^{* * *} \\
(0.106)\end{array}$ & $\begin{array}{c}0.350^{* * *} \\
(0.106)\end{array}$ \\
\hline Employee training & $\begin{array}{c}1.799^{* * *} \\
(0.544) \\
\end{array}$ & $\begin{array}{c}1.819^{* * *} \\
(0.543) \\
\end{array}$ & $\begin{array}{c}1.820 * * * \\
(0.544) \\
\end{array}$ & $\begin{array}{c}1.865^{* * *} \\
(0.543) \\
\end{array}$ & $\begin{array}{c}1.784^{* * *} \\
(0.543) \\
\end{array}$ \\
\hline Firm size & $\begin{array}{l}0.399 * \\
(0.214) \\
\end{array}$ & $\begin{array}{l}0.376^{*} \\
(0.214) \\
\end{array}$ & $\begin{array}{l}0.408^{*} \\
(0.214) \\
\end{array}$ & $\begin{array}{l}0.410 * \\
(0.213) \\
\end{array}$ & $\begin{array}{c}0.421 * * \\
(0.214) \\
\end{array}$ \\
\hline Annual sale & $\begin{array}{c}0.794^{* * *} \\
(0.168) \\
\end{array}$ & $\begin{array}{c}0.821^{* * *} \\
(0.168) \\
\end{array}$ & $\begin{array}{c}0.788^{* * *} \\
(0.168) \\
\end{array}$ & $\begin{array}{c}0.801 * * * \\
(0.168) \\
\end{array}$ & $\begin{array}{c}0.773^{* * * *} \\
(0.168) \\
\end{array}$ \\
\hline Industry & Yes & Yes & Yes & Yes & Yes \\
\hline \multicolumn{6}{|l|}{ Level 2} \\
\hline Legal institutions & & $\begin{array}{c}1.933 \\
(3.447) \\
\end{array}$ & $\begin{array}{c}2.042 \\
(3.457) \\
\end{array}$ & $\begin{array}{c}1.999 \\
(3.448) \\
\end{array}$ & $\begin{array}{c}2.014 \\
(3.452) \\
\end{array}$ \\
\hline Business regulations & & $\begin{array}{c}-5.027^{* * *} \\
(1.559) \\
\end{array}$ & $\begin{array}{c}-5.036^{* * *} \\
(1.564)\end{array}$ & $\begin{array}{c}-5.037 * * * \\
(1.560) \\
\end{array}$ & $\begin{array}{c}-5.028^{* * *} \\
(1.561) \\
\end{array}$ \\
\hline Financial systems & & $\begin{array}{c}1.638 \\
(1.802) \\
\end{array}$ & $\begin{array}{c}1.567 \\
(1.807)\end{array}$ & $\begin{array}{c}1.560 \\
(1.802)\end{array}$ & $\begin{array}{c}1.568 \\
(1.804)\end{array}$ \\
\hline Infrastructural supporting systems & & $\begin{array}{l}-1.243 \\
(2.120)\end{array}$ & $\begin{array}{l}-1.328 \\
(2.125)\end{array}$ & $\begin{array}{l}-1.284 \\
(2.120)\end{array}$ & $\begin{array}{l}-1.354 \\
(2.122)\end{array}$ \\
\hline \multicolumn{6}{|l|}{ Group means as level-2 controls } \\
\hline B-G ties & $\begin{array}{l}2.485 \\
2.029 \\
\end{array}$ & $\begin{array}{c}3.566 * * \\
(1.581) \\
\end{array}$ & $\begin{array}{c}3.597^{* *} \\
(1.586) \\
\end{array}$ & $\begin{array}{c}3.591 * * \\
(1.582) \\
\end{array}$ & $\begin{array}{c}3.592 * * \\
(1.584) \\
\end{array}$ \\
\hline Manager experience & $\begin{array}{c}0.217 \\
4.78\end{array}$ & $\begin{array}{l}-3.855 \\
(4.671)\end{array}$ & $\begin{array}{l}-3.911 \\
(4.685)\end{array}$ & $\begin{array}{l}-3.945 \\
(4.673)\end{array}$ & $\begin{array}{l}-3.827 \\
(4.678)\end{array}$ \\
\hline Competition & $\begin{array}{c}7.299^{* *} \\
3.073 \\
\end{array}$ & $\begin{array}{c}8.020^{* * *} \\
(2.819) \\
\end{array}$ & $\begin{array}{c}8.073^{* * *} \\
(2.827) \\
\end{array}$ & $\begin{array}{c}8.019^{* * *} \\
(2.820) \\
\end{array}$ & $\begin{array}{c}8.068^{* * *} \\
(2.823) \\
\end{array}$ \\
\hline Employee education & $\begin{array}{c}-.0437 \\
0.797 \\
\end{array}$ & $\begin{array}{c}0.722 \\
(0.709) \\
\end{array}$ & $\begin{array}{c}0.739 \\
(0.711) \\
\end{array}$ & $\begin{array}{c}0.734 \\
(0.709) \\
\end{array}$ & $\begin{array}{c}0.747 \\
(0.710) \\
\end{array}$ \\
\hline Employee training & $\begin{array}{l}5.352 \\
6.416 \\
\end{array}$ & $\begin{array}{c}7.142 \\
(5.295)\end{array}$ & $\begin{array}{c}7.383 \\
(5.310) \\
\end{array}$ & $\begin{array}{c}7.296 \\
(5.297) \\
\end{array}$ & $\begin{array}{c}7.378 \\
(5.302) \\
\end{array}$ \\
\hline Firm size & $\begin{array}{l}3.628 \\
3.193 \\
\end{array}$ & $\begin{array}{l}-0.646 \\
(2.657)\end{array}$ & $\begin{array}{l}-0.801 \\
(2.665) \\
\end{array}$ & $\begin{array}{l}-0.756 \\
(2.658)\end{array}$ & $\begin{array}{l}-0.736 \\
(2.660) \\
\end{array}$ \\
\hline Annual sale & $\begin{array}{l}-0.02 \\
2.206 \\
\end{array}$ & $\begin{array}{l}-0.149 \\
(1.785) \\
\end{array}$ & $\begin{array}{l}-0.181 \\
(1.790) \\
\end{array}$ & $\begin{array}{l}-0.172 \\
(1.785) \\
\end{array}$ & $\begin{array}{l}-0.224 \\
(1.787) \\
\end{array}$ \\
\hline \multicolumn{6}{|l|}{ Level $1 \times$ Level 2} \\
\hline B-G ties $\times$ Legal institutions & & $\begin{array}{c}-4.476^{* *} \\
(2.061)\end{array}$ & & & \\
\hline B-G ties $\times$ Business regulations & & & $\begin{array}{c}0.422 \\
(0.615) \\
\end{array}$ & & \\
\hline B-G ties $\times$ Financial systems & & & & $\begin{array}{c}1.993 * * \\
(0.811) \\
\end{array}$ & \\
\hline B-G ties $\times$ Infrastructural supporting systems & & & & & $\begin{array}{c}-2.521^{* *} \\
(1.119) \\
\end{array}$ \\
\hline Intercept & $\begin{array}{l}-14.356 \\
30.127\end{array}$ & $\begin{array}{c}3.603 \\
(25.33)\end{array}$ & $\begin{array}{c}4.563 \\
(25.40)\end{array}$ & $\begin{array}{l}4.456 \\
(25.34)\end{array}$ & $\begin{array}{c}4.688 \\
(25.36)\end{array}$ \\
\hline
\end{tabular}

Standard errors in parentheses. ${ }^{* * *} p<0.01,{ }^{* *} p<0.05,{ }^{*} p<0.1$. 
Table 10. Robustness checks: Standardize the product innovation relative to the industry average.

\begin{tabular}{|c|c|c|c|c|c|}
\hline Variables & Model 1 & Model 2 & Model 3 & Model 4 & Model 5 \\
\hline B-G ties & $\begin{array}{l}0.157^{* * * *} \\
(0.039)\end{array}$ & $\begin{array}{c}0.165^{* * * *} \\
(0.039)\end{array}$ & $\begin{array}{l}0.150^{* * * *} \\
(0.041)\end{array}$ & $\begin{array}{c}0.137^{* * *} \\
(0.040)\end{array}$ & $\begin{array}{l}0.181^{* * *} \\
(0.041)\end{array}$ \\
\hline B-G ties $\times$ Legal institutions & & $\begin{array}{l}-0.584 * * \\
(0.264) \\
\end{array}$ & & & \\
\hline $\mathrm{B}-\mathrm{G}$ ties $\times$ Business regulations & & & $\begin{array}{c}0.050 \\
(0.079)\end{array}$ & & \\
\hline B-G ties $\times$ Financial systems & & & & $\begin{array}{c}0.241 \text { ** } \\
(0.104)\end{array}$ & \\
\hline $\begin{array}{l}\text { B-G ties } \times \text { Infrastructural } \\
\text { supporting systems }\end{array}$ & & & & & $\begin{array}{l}-0.286^{* *} \\
(0.144) \\
\end{array}$ \\
\hline Controls & Yes & Yes & Yes & Yes & Yes \\
\hline Intercept & $\begin{array}{l}0.016 \\
(0.111)\end{array}$ & $\begin{array}{l}0.013 \\
(0.110)\end{array}$ & $\begin{array}{c}0.016 \\
(0.111)\end{array}$ & $\begin{array}{c}0.014 \\
(0.110)\end{array}$ & $\begin{array}{c}0.011 \\
(0.110)\end{array}$ \\
\hline
\end{tabular}

Table 11. Robustness checks: Heckman two-stage selection model.

\begin{tabular}{|c|c|c|c|c|c|}
\hline Variables & Model 1 & Model 2 & Model 3 & Model 4 & Model 5 \\
\hline B-G ties & $\begin{array}{c}1.293 * * * \\
(0.303)\end{array}$ & $\begin{array}{l}1.359^{* * * *} \\
(0.304)\end{array}$ & $\begin{array}{l}1.224^{* * * *} \\
(0.314)\end{array}$ & $\begin{array}{l}1.131^{* * *} \\
(0.309)\end{array}$ & $\begin{array}{l}1.484^{* * *} \\
(0.317)\end{array}$ \\
\hline B-G ties*Legal institutions & & $\begin{array}{l}-4.562 * * \\
(2.037)\end{array}$ & & & \\
\hline B-G ties*Business regulations & & & $\begin{array}{l}-0.488 \\
(0.606)\end{array}$ & & \\
\hline B-G ties*Financial systems & & & & $\begin{array}{l}2.0144^{* *} \\
(0.803)\end{array}$ & \\
\hline $\begin{array}{l}\text { B-G ties*Infrastructural } \\
\text { supporting systems }\end{array}$ & & & & & $\begin{array}{c}-2.249^{* *} \\
(1.106) \\
\end{array}$ \\
\hline Controls & Yes & Yes & Yes & Yes & Yes \\
\hline Cities & Yes & Yes & Yes & Yes & Yes \\
\hline Lambda & $\begin{array}{l}-3.990 \\
(3.063)\end{array}$ & $\begin{array}{l}-4.279 \\
(3.057)\end{array}$ & $\begin{array}{l}-3.95 \\
(3.063)\end{array}$ & $\begin{array}{l}-4.257 \\
(3.054)\end{array}$ & $\begin{array}{l}-4.248 \\
(3.058)\end{array}$ \\
\hline Intercept & $\begin{array}{l}4.182 \\
(8.50)\end{array}$ & $\begin{array}{l}4.182 \\
(8.50)\end{array}$ & $\begin{array}{l}4.182 \\
(8.50)\end{array}$ & $\begin{array}{l}4.182 \\
(8.50)\end{array}$ & $\begin{array}{l}4.182 \\
(8.50)\end{array}$ \\
\hline
\end{tabular}

Standard errors in parentheses; ${ }^{* * *} p<0.01,{ }^{* *} p<0.05,{ }^{*} p<0.1$.

Table 12. Robustness checks: Propensity score matching method.

\begin{tabular}{|c|c|c|c|c|c|}
\hline Variables & Model 1 & Model 2 & Model 3 & Model 4 & Model 5 \\
\hline B-G ties & $\begin{array}{l}1.781^{* *} \\
(0.897)\end{array}$ & $\begin{array}{l}1.723 * \\
(0.883)\end{array}$ & $\begin{array}{l}2.087^{* *} \\
(0.951)\end{array}$ & $\begin{array}{c}1.330 \\
(0.897)\end{array}$ & $\begin{array}{l}1.983 * * \\
(0.889)\end{array}$ \\
\hline B-G ties*Legal institutions & & $\begin{array}{l}-13.23^{* *} \\
(5.831)\end{array}$ & & & \\
\hline B-G ties*Business regulations & & & $\begin{array}{l}-1.520 \\
(2.176)\end{array}$ & & \\
\hline B-G ties*Financial systems & & & & $\begin{array}{l}5.825^{* * *} \\
(2.099)\end{array}$ & \\
\hline $\begin{array}{l}\text { B-G ties*Infrastructural } \\
\text { supporting systems }\end{array}$ & & & & & $\begin{array}{l}-5.788^{*} \\
(3.444)\end{array}$ \\
\hline Controls & Yes & Yes & Yes & Yes & Yes \\
\hline Intercept & $\begin{array}{l}6.413 * * * \\
(0.826)\end{array}$ & $\begin{array}{c}1.480 \\
(1.195)\end{array}$ & $\begin{array}{c}1.476 \\
(1.230)\end{array}$ & $\begin{array}{c}1.946 \\
(1.191)\end{array}$ & $\begin{array}{c}1.565 \\
(1.199)\end{array}$ \\
\hline
\end{tabular}

Standard errors in parentheses. ${ }^{* * *} p<0.01,{ }^{* *} p<0.05,{ }^{*} p<0.1$.

\section{Discussion and Conclusions}

\subsection{Contributions}

Building on IBV $[1,21]$, this study examined the extent to which B-G ties influence Chinese manufacturing firms' product innovation within different institutional environments. Empirical evidence indicated that the value of $\mathrm{B}-\mathrm{G}$ ties for product innovation varies in specific institutional contexts in transitional China. This result not only confirms the reported positive influence of B-G ties on firms' product innovation in transitional China $[8,15,28,88]$ but also provides fresh evidence for the contingent effects of institutional components on "B-G ties-firms' product innovation links" [5,7,14]. 
Particularly, our results revealed an interesting phenomenon: The positive influence of B-G ties on firms' product innovation may increase as financial systems further develop, which contradicts our theoretical proposition. A possible explanation for this reads as follows: Regarding the distribution of innovation-related financial resources, in China, the dominant role of the government remains intact at various degrees [21], even when the Chinese financial system is becoming more market-driven. In the last ten years, for example, the Chinese central and local governments have set up a large volume of government-dominated or government-backed seed funds, angel funds, and R\&D funds to induce, subsidize, and support firm technology and product innovation [97]. Under such conditions, the strategic value of $B-G$ ties in acquiring these financial funds may stay significant. Moreover, financial institutional reforms tend to regress in China. To make the financial systems more robust and stable, since the financial crisis in 2008, the Chinese government and SOEs have gradually increased control on the development of the financial industry, which is known by the Chinese term "Guojin Mintui" (i.e., "the state advance, the private sectors retreat") [98]. Under such circumstances, firms' financial resource allocations are more dependent on political power rather than on market power, which can be termed as a political market $[91,99]$. In such a political market, the development of related institutions may strengthen the role of B-G ties. Firms are inclined to maintain and reinforce existing B-G ties for dealing with potential uncertainties and negotiating for first-mover advantages when new financial rules are issued $[3,27,45]$.

These findings make several contributions to existing literature. Firstly, the findings add new evidence that the importance of $B-G$ ties will continue in China. This study shows that today's Chinese manufacturing firms' investment of energy and time in building and maintaining B-G ties is positively associated with product innovation. Particularly, stronger B-G ties lead to a higher benefit no matter which region they operate in, and no matter which institutional constraints they have to deal with. Building on this result, it can be proposed that the conducive effects of B-G ties on Chinese firms' product innovation can be persistent in an expected period, independent from the pace and content of the active institutional changes $[27,28]$.

Secondly, this paper contributes to an extension of the analytical boundaries of IBV by highlighting the specific effects of institutional components. Building on IBV, extant literature often treats the institution as a one-dimension entity $[11,58,100]$. However, theorists also substantiate that there are several institutional components and that each component may evolve on its own pace $[11,29,59]$. In line with this, this study decomposes institutions to specific subcomponents and examines their effects separately. The findings not only confirm the differentiated effects of institutional components but also go further. IBV theory argues that B-G ties and formal institutions are substitutable [21,38], i.e., the positive value of $\mathrm{B}-\mathrm{G}$ ties for innovation would be higher (less) in regions with less (higher) developed institutional environments [1,14]. This study's empirical findings partly support these IBV predictions. That is, the value of B-G ties in certain institutional environments may decline and in other environments may increase or remain the same as the institutions develop. More specifically, in Chinese cities with more efficient and fair legal institutions or infrastructural supporting systems, firms significantly reduce their dependence on B-G ties during product innovation activities. However, business regulations show an insignificant influence on the value of $B-G$ ties for firms' product innovation, whereas the value of B-G ties increases as financial systems move to higher developmental levels. These contrasting findings highlight the importance of distinguishing multiple institutional components in shaping the value of B-G ties for firms' product innovation [11]. Based on the above, it can be proposed that specific institutional components show specific ways of regulating, moderating, and shaping the effects of B-G ties on Chinese firms' product innovation, which can also be of a different nature.

Thirdly, this study finds empirical support for the proposition that B-G ties and institutional development may be complementary, which extends the understanding of the role of institutions in shaping the value of $B-G$ ties $[2,9]$. As discussed above, this study corroborates the positive moderation effects of financial systems on the "B-G ties-firms' product innovation links". This finding contradicts 
IBV's predictions, which can serve as input into the ongoing debate on whether or not $B-G$ ties continue to be important in transitional contexts like in China, also when they become more developed [27]. This empirical finding reveals a complementary relationship between the financial systems and B-G ties [15], which is largely ignored by previous IBV literature. Building on this reasoning, we may argue a complementary relationship between B-G ties and institutional development for firms' product innovation, which may extend previous substitutable perspectives [21,38].

Our findings can be of value for managerial practices in China. In general, this study supports the conclusion that firms with strong B-G ties benefit from it in their product innovation activities in Chinese contexts with underdeveloped as well as developed institutions but benefit more in cities with underdeveloped institutions. Based on this, senior managers in China can be stimulated to invest time and energy in building and maintaining B-G ties with governmental officials and be aware of the developmental state of the institutions in their cities and develop an informed judgement as to what degree these ties are needed to support their product innovation activities. Moreover, it reveals that regional institutional environments in transitional China can play an important role in determining the value of $\mathrm{B}-\mathrm{G}$ ties regarding manufacturing firms' product innovation. Building on this, managers further need to adjust their B-G networking activity to adapt to the nature and developmental phase of specific institutions they have to deal with. To fund firms' innovation projects, for example, keeping conducive interactions with government officials could extract valued assets that benefit firms' product innovation. Thus, tailored and versatile B-G strategies seem to be necessary for firms that operate in different cities in transitional China.

This study also has implications for Chinese policy makers. Although the importance of B-G ties will stay important in Chinese settings, our findings indicate that stronger B-G ties may constrain firms' product innovation in cities with more developed institutions. Therefore, policy makers could concentrate on constraining the abusive use of individual power by officials by means of implementing a position-rotating policy and an anticorruption policy. Moreover, $\mathrm{B}-\mathrm{G}$ ties are embedded in specific regional institutions. This implies that governmental policy could focus on developing institutional environments not only at a country level but explicitly focus on a local level as well. Particularly, policy makers could pay attention to the disparities among institution components, and tailored policy could be more appropriate. In addition to this, institutional reform can be a crucial driver in moving China to become a more innovative country and economy. Recent years show that more and more Chinese manufacturing firms are born that do business without heavily relying upon B-G ties. Market-based channels appear to be a main imperative for them to obtain the required resources for innovation purposes. To further stimulate Chinese firms to adopt such an approach, the Chinese government could continue its institutional reforms in that direction, which can motivate and initiate firms' innovation activities.

\subsection{Limitations and Future Research}

Some limitations of this study can direct future research. First, due to the cross-sectional nature of the data used, this study cannot reveal the dynamic relationship between the change of B-G ties and the development of institutions. Future work can develop insights into these dynamics using a longitudinal research design. The cross-sectional data also constrain this study in dealing with interpretations among focal variables. For example, innovative firms may get more attention from the local government or be more likely to be invited to attend government meetings, while less innovative firms may be ignored. Future studies can explore this complex relationship by conducting panel data analysis or experimental studies. Furthermore, this study's analysis of the contingent effects of the formal institutions (i.e., legal institutions and economic institutions), and no attention on informal institutions, may limit the reported insights. Informal institutions may also shape the value of B-G ties and their effect on firms' product innovation [1,24]. Future research can further explore how informal institutions, especially the interdependence of formal and informal institutions, lead the value and effect of B-G ties to be more complicated (e.g., curvilinear or regressive). In addition, the results of 
this study are constrained to a specific empirical context, i.e., cities in China. Generalizing the results to other transitional countries, such as Russia, is problematic. Further testing in other transitional economies would enrich the insights on the relationship between B-G ties, firms' product innovation, and institutional components.

Author Contributions: For this research article, C.Y. conceived, designed, drafted, and edited the manuscript, B.B. and P.P. guided, supervised, reviewed, and edited the manuscript.

Funding: This research received no external funding.

Acknowledgments: The authors would like to thank the editors and all anonymous referees for their suggestive comments.

Conflicts of Interest: The authors declare no conflict of interest.

\section{Appendix A}

Table A1. The measure of focal variables drawing from World Bank's Enterprise Survey.

\begin{tabular}{|c|c|}
\hline Variables & Survey Questions \\
\hline Product innovation & $\begin{array}{l}\text { 1. In fiscal year 2011, what percent of this establishment's total annual sales was accounted for by products or services that were } \\
\text { introduced in the last three years? } \\
\text { 2. In fiscal year 2011, what were this establishment's total annual sales for ALL products and services? }\end{array}$ \\
\hline B-G ties & $\begin{array}{l}\text { 1. In a typical week over the last year, what percentage of total senior management's time was spent on dealing with } \\
\text { requirements imposed by government regulations? }\end{array}$ \\
\hline Legal institution & $\begin{array}{l}\text { 1. The court system is fair, impartial and uncorrupted. [ } 1 \text { Strongly disagree, } 2 \text { Tend to disagree, } 3 \text { Tend to agree, } 4 \text { Strongly agree] } \\
\text { 2. To what degree is / are Courts an obstacle to the current operations of this establishment? [0 No obstacle, } 1 \text { Minor obstacle, } 2 \\
\text { Moderate obstacle, } 3 \text { Major obstacle, } 4 \text { Very severe obstacle] }\end{array}$ \\
\hline Business regulation & $\begin{array}{l}\text { 1. To what degree is/are Tax Rates an obstacle to the current operations of this establishment? [0 No obstacle, } 1 \text { Minor obstacle, } \\
2 \text { Moderate obstacle, } 3 \text { Major obstacle, } 4 \text { Very severe obstacle] } \\
\text { 2. To what degree is/are Tax Administration an obstacle to the current operations of this establishment? [0 No obstacle, } 1 \text { Minor } \\
\text { obstacle, } 2 \text { Moderate obstacle, } 3 \text { Major obstacle, } 4 \text { Very severe obstacle] } \\
\text { 3. To what degree is/are Business Licensing and Permits an obstacle to the current operations of this establishment? [0 No } \\
\text { obstacle, } 1 \text { Minor obstacle, } 2 \text { Moderate obstacle, } 3 \text { Major obstacle, } 4 \text { Very severe obstacle] }\end{array}$ \\
\hline Financial systems & $\begin{array}{l}\text { 1. To what degree is Access to Finance an obstacle to the current operations of this establishment? [0 No obstacle, } 1 \text { Minor } \\
\text { obstacle, } 2 \text { Moderate obstacle, } 3 \text { Major obstacle, } 4 \text { Very severe obstacle] }\end{array}$ \\
\hline $\begin{array}{l}\text { Infrastructure } \\
\text { supporting systems }\end{array}$ & $\begin{array}{l}\text { 1. To what degree is Electricity an obstacle to the current operations of this establishment? [0 No obstacle, } 1 \text { Minor obstacle, } 2 \\
\text { Moderate obstacle, } 3 \text { Major obstacle, } 4 \text { Very severe obstacle] } \\
\text { 2. To what degree is Telecommunications an obstacle to the current operations of this establishment? [0 No obstacle, } 1 \text { Minor } \\
\text { obstacle, } 2 \text { Moderate obstacle, } 3 \text { Major obstacle, } 4 \text { Very severe obstacle] }\end{array}$ \\
\hline
\end{tabular}

\section{References}

1. Peng, M.W. Institutional transitions and strategic choices. Acad. Manag. Rev. 2003, 28, 275-296. [CrossRef]

2. Peng, M.W.; Luo, Y. Managerial ties and firm performance in a transition economy: The nature of a Micro-Macro link. Acad. Manag. J. 2000, 43, 486-501. [CrossRef]

3. Child, J.; Tse, D.K. China's transition and its implications for international business. J. Int. Bus. Stud. 2001, 32, 5-21. [CrossRef]

4. Meyer, K.E.; Nguyen, H.V. Foreign investment strategies and sub-national institutions in emerging markets: Evidence from Vietnam. J. Manag. Stud. 2005, 42, 63-93. [CrossRef]

5. Sheng, S.; Zhou, K.Z.; Li, J. The effects of business and political ties on firm performance: Evidence from China. J. Mark. 2011, 75, 1-15. [CrossRef]

6. Zhou, K.Z.; Gao, G.Y.; Zhao, H. State ownership and firm innovation in China: An integrated view of institutional and efficiency logics. Adm. Sci. Q. 2017, 62, 375-404. [CrossRef]

7. Sun, P.; Mellahi, K.; Wright, M. The contingent value of corporate political ties. Acad. Manag. Perspect. 2012, 26, 68-82. [CrossRef]

8. Kotabe, M.; Jiang, C.X.; Murray, J.Y. Examining the complementary effect of political networking capability with absorptive capacity on the innovative performance of emerging-market firms. J. Manag. 2017, 43, 1131-1156. [CrossRef]

9. $\mathrm{Li}, \mathrm{H} . ; \mathrm{Zhang}$, $\mathrm{Y}$. The role of managers' political networking and functional experience in new venture performance: Evidence from China's transition economy. Strateg. Manag. J. 2007, 28, 791-804. [CrossRef]

10. Shaffer, B.; Hillman, A.J. The development of business-government strategies by diversified firms. Strateg. Manag. J. 2000, 21, 175-190. [CrossRef] 
11. Zheng, W.; Singh, K.; Chung, C.-N. Ties to unbind: Political ties and firm sell-offs during institutional transition. J. Manag. 2017, 43, 2005-2036. [CrossRef]

12. Zheng, W.; Singh, K.; Mitchell, W. Buffering and enabling: The impact of interlocking political ties on firm survival and sales growth. Strateg. Manag. J. 2015, 36, 1615-1636. [CrossRef]

13. Meyer, K.E.; Estrin, S.; Bhaumik, S.K.; Peng, M.W. Institutions, resources, and entry strategies in emerging economies. Strateg. Manag. J. 2009, 30, 61-80. [CrossRef]

14. Gao, Y.; Shu, C.; Jiang, X.; Gao, S.; Page, A.L. Managerial ties and product innovation: The moderating roles of macro- and micro-institutional environments. Long Range Plan. 2017, 50, 168-183. [CrossRef]

15. Schott, T.; Jensen, K.W. Firms' innovation benefiting from networking and institutional support: A global analysis of national and firm effects. Res. Policy 2016, 45, 1233-1246. [CrossRef]

16. Lin, C.; Lin, P.; Song, F. Property rights protection and corporate R\&D: Evidence from China. J. Dev. Econ. 2010, 93, 49-62. [CrossRef]

17. Wu, J. Asymmetric roles of business ties and political ties in product innovation. J. Bus. Res. 2011, 64, 1151-1156. [CrossRef]

18. Chan, C.M.; Makino, S.; Isobe, T. Does subnational regions matter? Foreign affiliate performance in the United States and China. Strateg. Manag. J. 2010, 31, 1226-1243. [CrossRef]

19. Shi, W.S.; Sun, S.L.; Peng, M.W. Sub-national institutional contingencies, network positions, and IJV partner selection. J. Manag. Stud. 2012, 49, 1221-1245. [CrossRef]

20. He, C.; Wei, Y.D.; Xie, X. Globalization, institutional change, and industrial location: Economic transition and industrial concentration in China. Reg. Stud. 2008, 42, 923-945. [CrossRef]

21. Peng, M.W.; Wang, D.Y.L.; Jiang, Y. An institution-based view of international business strategy: A focus on emerging economies. J. Int. Bus. Stud. 2008, 39, 920-936. [CrossRef]

22. North, D.C. Institutions, Institutional Change, and Economic Performance; Cambridge University Press: New York, NY, USA, 1990.

23. Oliver, C. Sustainable competitive advantage: Combining institutional and resource based views. Strateg. Manag. J. 1997, 19, 697-713. [CrossRef]

24. Peng, M.W.; Sun, S.L.; Pinkham, B.; Chen, H. The Institution-based view as a third leg for a strategy tripod. Acad. Manag. Perspect. 2009, 23, 63-81. [CrossRef]

25. Wright, M.; Filatotchev, I.; Hoskisson, R.E.; Peng, M.W. Strategy research in emerging economies: Challenging the conventional wisdom. J. Manag. Stud. 2005, 42, 1-33. [CrossRef]

26. Park, S.H.; Li, S.; Tse, D.K. Market liberalization and firm performance during China's economic transition. J. Int. Bus. Stud. 2006, 37, 127-147. [CrossRef]

27. Michelson, E. Lawyers, political embeddedness and institutional continuity in China's transition from socialism. Am. J. Sociol. 2007, 113, 352-414. [CrossRef]

28. Shi, W.S.; Markoczy, L.; Stan, C.V. The continuing importance of political ties in China. Acad. Manag. Perspect. 2014, 28, 57-75. [CrossRef]

29. Nee, V.; Opper, S. Political capital in a market economy. Soc. Forces 2010, 88, 2105-2132. [CrossRef]

30. Galang, R.M.N. Government efficiency and international technology adoption: The spread of electronic ticketing among airlines. J. Int. Bus. Stud. 2012, 43, 631-654. [CrossRef]

31. Granville, B.; Leonard, C.S. Do informal institutions matter for technological change in Russia? The impact of communist norms and conventions, 1998-2004. World Dev. 2010, 38, 155-169. [CrossRef]

32. Zhu, Y.; Wittmann, X.; Peng, M.W. Institution-based barriers to innovation in SMEs in China. Asia Pac. J. Manag. 2012, 29, 1131-1142. [CrossRef]

33. Marquis, C.; Raynard, M. Institutional strategies in emerging markets. Acad. Manag. Ann. 2015, 9, $291-335$. [CrossRef]

34. World Bank. World Bank's Enterprise Survey: Understanding the Questionnaire; World Bank: Washington, DC, USA, 2011. (In English)

35. Luu, N.; Ngo, L.V. Entrepreneurial orientation and social ties in transitional economies. Long Range Plan. 2018. [CrossRef]

36. Chan, C.M.; Isobe, T.; Makino, S. Which country matters? Institutional development and foreign affiliate performance. Strateg. Manag. J. 2008, 29, 1179-1205. [CrossRef]

37. Khanna, T.; Palepu, K. The future of business groups in emerging markets: Long-run evidence from Chile. Acad. Manag. J. 2000, 43, 268-285. [CrossRef] 
38. Xin, K.R.; Pearce, J.L. Guanxi: Connections as substitutes for formal institutional support. Acad. Manag. J. 1996, 39, 1641-1658. [CrossRef]

39. Suchman, M.C. Managing legitimacy: Strategic and institutional approaches. Acad. Manag. Rev. 1995, 20, 571-610. [CrossRef]

40. Oliver, C. Strategic responses to institutional processes. Acad. Manag. Rev. 1991, 16, 145-179. [CrossRef]

41. Teece, D.J. Profiting from technological innovation: Implications for integration, collaboration, licensing and public policy. Res. Policy 1986, 15, 285-305. [CrossRef]

42. Goldman, E.; Rocholl, J.; So, J. Politically connected boards of directors and the allocation of procurement contracts. Rev. Financ. 2013, 17, 1617-1648. [CrossRef]

43. Hillman, A.J.; Hitt, M.A. Corporate political strategy formulation: A model of approach, participation, and strategy decisions. Acad. Manag. Rev. 1999, 24, 825-842. [CrossRef]

44. Faccio, M.; Masulis, R.W.; McConnell, J.J. Political connections and corporate bailouts. J. Financ. 2006, 61, 2597-2635. [CrossRef]

45. Khwaja, A.I.; Mian, A. Do lenders favor politically connected firms? Rent provision in an emerging financial market. Q. J. Econ. 2005, 120, 1371-1411. [CrossRef]

46. Li, J.J. The formation of managerial networks of foreign firms in China: The effects of strategic orientations. Asia Pac. J. Manag. 2005, 22, 423-443. [CrossRef]

47. Welter, F.; Kautonen, T.; Chepurenko, A.; Malieva, E. Trust environments and entrepreneurial behavior-Exploratory evidence from Estonia, Germany and Russia. J. Enterp. Cult. 2004, 12, 327-349. [CrossRef]

48. Priem, R.L.; Butler, J.E. Is the resource-based "view" a useful perspective for strategic management research? Acad. Manag. Rev. 2001, 26, 22-40. [CrossRef]

49. Katila, R.; Shane, S. When does lack of resources make new firms innovative? Acad. Manag. J. 2005, 48, 814-829. [CrossRef]

50. Powell, W.W.; Koput, K.W.; Smith-Doerr, L. Interorganizational collaboration and the locus of innovation: Networks of learning in biotechnology. Adm. Sci. Q. 1996, 41, 116-145. [CrossRef]

51. Mahmood, I.P.; Rufin, C. Government's dilemma: The role of government in imitation and innovation. Acad. Manag. Rev. 2005, 30, 338-360. [CrossRef]

52. Makino, S.; Isobe, T.; Chan, C.M. Does country matter? Strateg. Manag. J. 2004, 25, 1027-1043. [CrossRef]

53. Ahlstrom, D.; Bruton, G.D.; Yeh, K.S. Private firms in China: Building legitimacy in an emerging economy. J. World Bus. 2008, 43, 385-399. [CrossRef]

54. Lu, Y.; Tsang, E.W.K.; Peng, M.W. Knowledge management and innovation strategy in the Asia Pacific: Toward an institution-based view. Asia Pac. J. Manag. 2008, 25, 361-374. [CrossRef]

55. Zimmerman, M.A.; Zeitz, G.J. Beyond survival: Achieving new venture growth by building legitimacy. Acad. Manag. Rev. 2002, 27, 414-431. [CrossRef]

56. Peng, M.W.; Heath, P.S. The growth of the firm in planned economies in transition: Institutions, organizations, and strategic choice. Acad. Manag. Rev. 1996, 21, 492-528. [CrossRef]

57. North, D.C. Institutions and the process of economic change. Manag. Int. 2005, 9, 1-7.

58. Acemoglu, D.; Johnson, S. Unbundling institutions. J. Political Econ. 2005, 113, 949-995. [CrossRef]

59. Yang, X.; Sun, S.L.; Yang, H. Market-based reforms, synchronization and product innovation. Ind. Mark. Manag. 2015, 50, 30-39. [CrossRef]

60. Li, H.; Meng, L.; Wang, Q.; Zhou, L. Political connections, financing and firm performance: Evidence from Chinese private firms. J. Dev. Econ. 2008, 87, 283-299. [CrossRef]

61. Schlevogt, K.-A. Institutional and organizational factors affecting effectiveness: Geoeconomic comparison between Shanghai and Beijing. Asia Pac. J. Manag. 2001, 18, 519-551. [CrossRef]

62. Acemoglu, D.; Dell, M. Productivity differences between and within countries. Am. Econ. J. Macroecon. 2010, 2, 169-188. [CrossRef]

63. Luo, Y. Are Joint Venture Partners More Opportunistic in a More Volatile Environment? Strateg. Manag. J. 2007, 28, 39-60. [CrossRef]

64. Ahuja, G.; Yayavaram, S. Explaining influence rents: The case for an institutions-based view of strategy. Organ. Sci. 2011, 22, 1631-1652. [CrossRef]

65. Casson, M.C.; Giusta, M.D.; Kambhampati, U.S. Formal and informal institutions and development. World Dev. 2010, 38, 137-141. [CrossRef] 
66. Lenartowicz, T.; Roth, K. Does subculture within a country matter? A cross-culture study of motivational domains and business performance in Brazil. J. Int. Bus. Stud. 2001, 32, 305-325. [CrossRef]

67. Williamson, O.E. Transaction cost economics and organization theory. Inst. Corp. Chang. 1993, 2, 107-156. [CrossRef]

68. Nguyen, H.; Jaramillo, P.A. Institutions and Firms' Return to Innovation: Evidence from the World Bank Enterprise Survey; World Bank Policy Research Working Paper No. 6918; World Bank: Washington, DC, USA, 2014.

69. Oluwatobi, S.; Efobi, U.; Olurinola, I.; Alege, P. Innovation in Africa: Why institutions matter. S. Afr. J. Econ. 2015, 83, 390-410. [CrossRef]

70. Perks, H.; Kahn, K.; Zhang, C. An empirical evaluation of R\&D-marketing NPD integration in Chinese firms: The guanxi effect. J. Prod. Innov. Manag. 2009, 26, 640-651. [CrossRef]

71. Peng, M.W.; Zhou, J.Q. How network strategies and institutional transitions evolve in Asia. Asia Pac. J. Manag. 2005, 22, 321-336. [CrossRef]

72. Zhang, J.; Tan, J.; Wong, P.K. When does investment in political ties improve firm performance? The contingent effect of innovation activities. Asia Pac. J. Manag. 2015, 32, 363-387. [CrossRef]

73. Myers, S.C. The capital structure puzzle. J. Financ. 1984, 39, 575-592. [CrossRef]

74. Levie, J.; Autio, E. A theoretical grounding and test of the GEM model. Small Bus. Econ. 2008, 31, $235-263$. [CrossRef]

75. Bygrave, W.; Hay, M.; Ng, E.; Reynolds, P.D. Executive forums: A study of informal investing in 29 nations composing Global Entrepreneurship Monitor. Venture Cap. Int. J. Entrep. Financ. 2003, 5, 101-116. [CrossRef]

76. Kusnadi, Y.; Yang, Z.; Zhou, Y. Institutional development, state ownership, and corporate cash holdings: Evidence from China. J. Bus. Res. 2015, 68, 351-359. [CrossRef]

77. Luo, Y. Industrial dynamics and managerial networking in an emerging market: The case of China. Strateg. Manag. J. 2003, 24, 1315-1327. [CrossRef]

78. Hoskisson, R.E.; Wright, M.; Fitatotchev, I.; Peng, M.W. Emerging multinationals from Mid-range economies: The influence of institutions and factor markets. J. Manag. Stud. 2013, 50, 1295-1321. [CrossRef]

79. Meon, P.-G.; Weill, L. Is corruption an efficient grease? World Dev. 2010, 38, 244-259. [CrossRef]

80. Hipp, C.; Grupp, H. Innovation in the service sector: The demand for service-specific innovation measurement concepts and typologies. Res. Policy 2005, 34, 517-535. [CrossRef]

81. Smith, K. Measuring innovation. In The Oxford Handbook of Innovation; Fagerberg, J., Mowery, D.C., Nelson, R.R., Eds.; Oxford University Press: Oxford, UK, 2005; pp. 148-177.

82. Laursen, K.; Salter, A. Open for innovation: The role of openness in explaining innovation performance among UK manufacturing firms. Strateg. Manag. J. 2006, 27, 131-150. [CrossRef]

83. Bliese, P.D. Within-group agreement, non-independence, and reliability: Implications for data aggregation and analysis. In Multilevel Theory, Research, and Methods in Organizations: Foundations, Extensions, and New Directions; Klein, K.J., Kozlowski, S.W.J., Eds.; Jossey-Bass: San Francisco, CA, USA, 2000; pp. 349-381.

84. Wang, X.; Fan, G.; Yu, J. Marketization Index of China's Provinces: NERI Report 2016; Social Sciences Academic Press: Beijing, China, 2016.

85. Gaur, A.S.; Lu, J.W. Ownership strategies and survival of foreign subsidiaries: Impacts of institutional distance and experience. J. Manag. 2007, 33, 84-110. [CrossRef]

86. Kuncic, A. Institutional quality dataset. J. Inst. Econ. 2014, 10, 135-161. [CrossRef]

87. Kaufmann, D.; Kraay, A.; Mastruzzi, M. The Worldwide Governance Indicators Project: Answering the Critics; World Bank Policy Research Working Paper No. 4149; World Bank: Washington, DC, USA, 2007.

88. Shu, C.; Page, A.L.; Gao, S.; Jiang, X. Managerial ties and firm innovation: Is knowledge creation a missing link? J. Prod. Innov. Manag. 2012, 29, 125-143. [CrossRef]

89. Acquaah, M. Managerial social capital, strategic orientation, and organizational performance in an emerging economy. Strateg. Manag. J. 2007, 28, 1235-1255. [CrossRef]

90. Snijders, T.A.B.; Bosker, R.J. Multilevel Analysis: An Introduction to Basic and Advanced Multilevel Modeling, 2nd ed.; Sage Publishers: London, UK, 2012.

91. Zhou, W. Regional institutional development, political connections, and entrepreneurial performance in China's transition economy. Small Bus. Econ. 2014, 43, 161-181. [CrossRef]

92. Wooldridge, J.M. Fixed-effects and related estimators for correlated random-coefficient and treatment-effect panel data models. Rev. Econ. Stat. 2005, 87, 385-390. [CrossRef] 
93. Aguinis, H.; Gottfredson, R.K.; Culpepper, S.A. Best-practice recommendations for estimating cross-level interaction effects using multilevel modeling. J. Manag. 2013, 39, 1490-1528. [CrossRef]

94. Hofmann, D.A.; Gavin, M.B. Centering decisions in hierarchical linear models: Implications for research in organizations. J. Manag. 1998, 24, 623-641. [CrossRef]

95. Cohen, W.M.; Levinthal, D.A. Absorptive capacity: A new perspective on learning and innovation. Adm. Sci. Q. 1990, 35, 128-152. [CrossRef]

96. Guo, S.Y.; Fraser, M.W. Propensity Score Analysis: Statistical Methods and Applications; SAGE Publications, Inc.: Thousand Oaks, CA, USA, 2009.

97. Guo, D.; Guo, Y.; Jiang, K. Government-subsidized R\&D and firm innovation: Evidence from China. Res. Policy 2016, 45, 1129-1144. [CrossRef]

98. Thornton, P.M. The advance of the party: Transformation or takeover of urban grassroots society? China $Q$. 2013, 213, 1-18. [CrossRef]

99. Boisot, M.; Child, J. From fiefs to clans and network capitalism: Explaining China's emerging economic order. Adm. Sci. Q. 1996, 41, 600-628. [CrossRef]

100. Lin, R.; Peng, T.; Zhang, H. Venture capital reputation and portfolio firm performance in an emerging economy: The moderating effect of institutions. Asia Pac. J. Manag. 2017, 34, 699-723. [CrossRef]

(c) 2018 by the authors. Licensee MDPI, Basel, Switzerland. This article is an open access article distributed under the terms and conditions of the Creative Commons Attribution (CC BY) license (http:/ / creativecommons.org/licenses/by/4.0/). 